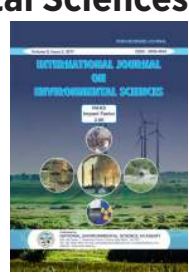

\title{
ECOLOGICAL RESTORATION OF EARTH'S ECOSYSTEM AND THE DECADE OF ECOSYSTEM RESTORATION
}

\author{
Debasmita Patra $^{1}$ and Saikat Kumar Basu ${ }^{2^{*}}$ \\ ${ }^{1}$ Department of Botany, West Bengal State University, North 24 Parganas, West Bengal, India \\ ${ }^{2}$ PFS, Lethbridge Alberta Canada
}

\section{Research Article}

Received: 14.10.2021

Accepted: 18.10.2021

Published: 27.10.2021

\begin{abstract}
Restoration ecology has demonstrated an astounding growth as a new discipline of applied science, since its emergence in the past decades. Future-aimed restoration should acknowledge the changing and unpredictable environment of the future, assume the dynamic nature of ecological communities with multiple trajectories, and connect landscape elements for improving ecosystem functions and structures. Ecosystem loss is depriving the world of carbon sinks, like forests and wetlands, at a time when humanity can least afford it. Ecosystem restoration aims to repair some damage done to the environment and regain ecological functionality. The United Nations (UN) recently declared 2021 to 2030 the Decade on Ecosystem Restoration- a global mission to revive billions of hectares, from forests to farmlands, from the top of mountains to the depth of the sea. The path to a more sustainable use of ecosystems must begin with the development of inclusive wealth measures which capture natural, social, human and manufactured capital and are thus more accurate ways to measure economic progress.
\end{abstract}

Keywords: Ecosystem Restoration, United Nations Environment Programme, Indian Forest, Sustainable Development Goals, Ecology.

\begin{abstract}
ABBREVIATIONS: CBD-Convention on Biological Diversity, FAO-Food and Agriculture Organization, FESFoundation for Ecological Security, FRA-Global Forest Resources Assessment, GHG-Greenhouse gases, HULHindustan Unilever Limited, ISER-India State of Forest Report, JFMC-Joint Forest Management Committee, NCF-Nature Conservation Foundation, SDG-Sustainable Development Goals, SEEAEA-System of Environmental Economic Accounting Ecosystem Accounting, NTFPsNon-timber forest products, UN-United Nations, UNCCD-United Nations Convention to Combat Desertification, UNEP-United Nations Environment Programme, UNESCO-United Nations Educational, Scientific and Cultural Organization, UNFCCC-United Nations Framework Convention on Climate Change.
\end{abstract}

\section{INTRODUCTION}

Ecological restoration aims to initiate the recovery of an ecosystem following damage, degradation, or destruction. Restoration practitioners create the conditions needed for recovery so the plants, animals, and microorganisms can carry out the work of recovery themselves. The ecosystem may not necessarily recover to its former state since contemporary ecological realities, including global climate change, may cause it to develop along an altered trajectory, just as these same realities may have changed the trajectory of nearby undisturbed ecosystems.

Ecological restoration aims to re-establish or recreate a selforganizing ecosystem on a trajectory to reach full recovery. While restoration activities can often place a degraded

*Corresponding author: saikat.basu@alumni.uleth.ca 
ecosystem on an initial trajectory of recovery relatively quickly, full recovery of the ecosystem can take years, decades, or even hundreds of years. For example, while we can initiate a forest restoration process by planting trees, for full recovery to be achieved, the site should be a fully functioning forest with mature trees in the ageclasses representative of a mature native forest. If there were 500-year-old trees in the forest that was destroyed, then the restoration should logically take hundreds of years to achieve full recovery. During that recovery period, unforeseen barriers to recovery may be encountered, or additional restoration activities may become possible at later stages of development.

Ecosystem Restoration is defined as "a process of the reversing the degradation of ecosystems, such as landscapes, lakes and oceans to region their ecological functionality; in other words, to improve the productivity and capacity of ecosystems to meet the needs of society. This can be done band capacity of ecosystems to meet the needs of society. This can be done by allowing the natural regeneration of overexploited ecosystems or by planting trees and others plants” (UNEP, 2019).

The restoration of ecosystem aims at the preservation and sustainable utilization of biodiversity. Such establishment of a healthy and connected ecosystem targets the degraded state of the environment, improves people's livelihood, increases food and water security, which are vital for the well-being of human beings and social, economic and environmental development (CBD, 2019). If ecosystems are considered as socio-ecological areas that are beneficial to various stakeholders and give multiple returns, it will become easier to detect the causes of ecosystem degradation and manage the losses and work for their sustainable development (IUCN, 2008).

Ecosystem restoration is "any intentional activity that initiates or accelerates the recovery of an ecosystem from a degraded state"; the deliberate act of renewal, recovery and reestablishment of damaged or destroyed ecosystems and the restoration processes or treatments entirely depend on the types of the ecosystem. To restore an ecosystem having functional benefits, the approach must include strategies with proper knowledge regarding the landscape level, local conditions etc. (IPBES, 2018; CBD, 2019).

\section{The Restoration Principles given by CBD (CBD, 2019)}

- It provides complementation but conservation activities cannot be substitute instead.

- It should correspond to CBD rules and regulations following ecosystem principles.

- It should be measured in multiple scales and according implemented in preferred to science vision.

On 1 March 2019, the United Nations General Assembly proclaimed 2021-2030 to be the United Nations Decade on Ecosystem Restoration. All initiatives within the UN Decade will consequently have a dual focus on protecting as well as restoring ecosystems. Integrated land-use planning, undertaken in a rights-based manner, where all stakeholders are informed of the full range of benefits to be gained through conservation, restoration and sustainable use of natural resources in their local ecosystems, assists in achieving this balance. The United Nations Environment Programme (UNEP) and Food and Agriculture Organization (FAO) along with their partners will provide leadership, coordination and technical support throughout the UN Decade.

Healthy, stable and biodiverse ecosystems are the foundation of our health and well-being, as well as that of our fellow species. They help to regulate our climate and control extreme events, pests and diseases, as well as to provide us with water, food, raw materials and spaces for recreation. They absorb our wastes, sustain economic sectors and the livelihoods of millions of people, and they nurture our health, culture and spiritual fulfillment (IPBES, 2019).

However, we have been over exploiting and degrading the world's ecosystems and wild species, causing the erosion of the very services we depend on (UNEP, 2021). Driving this degradation are the ways we produce food and alter our landscapes and oceans, along with climate change, pollution and invasive species (IPBES, 2019; Benton et al., 2021).

All selected ecosystems - farmlands; forests; freshwater; grasslands, shrublands and savannahs; mountains; oceans and coasts; peatlands; and urban areas - are being degraded, often at an accelerating rate. We are fast approaching a tipping point for the 
climate and are close to overshooting some of our other 'planetary boundaries' (IPCC, 2018).

Degradation is undermining hard-won development gains and threatening the well-being of today's youth and future generations, while making national commitments increasingly more difficult and costly to reach. None of the agreed global goals for the protection of life on Earth and for halting the degradation of land and oceans have been fully met and only 6 of the 20 Aichi Biodiversity Targets have been partially achieved (CBD, 2020; UNEP, 2021). We need to re-create a balanced relationship with nature, not only by conserving ecosystems that are still healthy, but also by urgently and sustainably restoring degraded ones.

Much has been done already, and we can build on the lessons learned from existing restoration approaches and initiatives. Commitments by 115 governments to restore a total of nearly 1 billion hectares of land as a contribution to achieving the objectives of the CBD, UNCCD, UNFCCC and the Bonn Challenge are a good start. The UN Decade on Ecosystem Restoration aims to prevent, halt and reverse the degradation of all kinds of ecosystems, contributing to reductions in global poverty and ensuring that no one is left behind. Running from 2021 until 2030, the UN Decade launches a global movement to restore ecosystems worldwide. This will help to achieve multiple global goals, including the Post-2020 Global Biodiversity Framework under the CBD, the Paris Agreement under the UNFCCC, the Sustainable Development Goals (SDGs) under 2030 Agenda and the Land Degradation Neutrality targets under the UNCCD. There are also clear complementarities with the efforts being developed in both the UN Decade of Ocean Science for Sustainable Development (2021-2030) and the UN Decade of Family Farming (2019-2028). The UN Food Systems Summit 2021 provides an opportunity to promote scaled up action on restoring farmlands and other food-producing systems. It also presents the overall strategy for the UN Decade and the way forward.

The impacts of the COVID-19 pandemic will be felt for generations. Yet this crisis has also demonstrated the power of international cooperation and provided us with an opportunity to steer away from our current destructive trajectory (UNEP 2021). To put countries on a path that is green, sustainable and fair, national governments must include ecosystem restoration in their pandemic recovery plans. This Decade can serve as a launch pad to accelerate the transformative changes we need to combat the climate crisis, prevent mass extinctions and build social and economic resilience.

\section{The Aims for the UN Decade}

The UN Decade has the overarching goal to prevent, halt and reverse the degradation of ecosystems around the world. The vision for the UN Decade is a world where - for the health and well-being of all life on Earth and that of future generations - the relationship between humans and nature has been restored, where the area of healthy ecosystems is increasing and where ecosystem loss, fragmentation and degradation has been ended. This is an endeavor that no single entity can undertake alone. It requires political will, innovation and collaboration. The UN Decade aims to catalyze the delivery of existing restoration goals, targets and initiatives, as well as the development of new ambitions for impact (Fig 1).

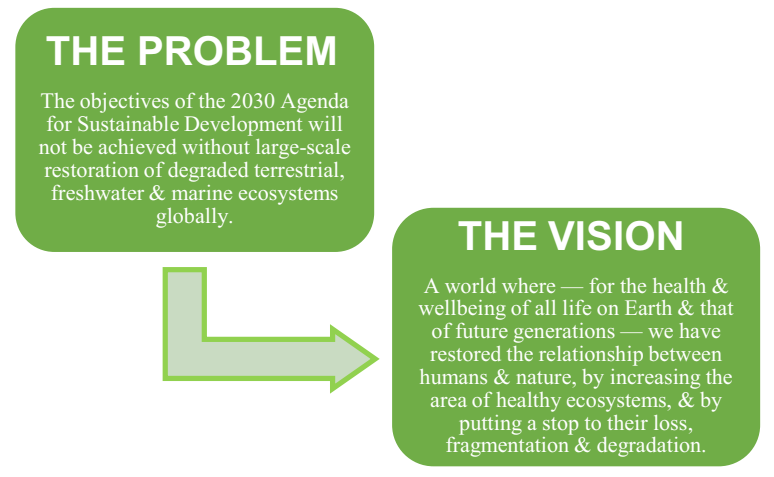

Fig 1. Plan for UN Decade Ecosystem Restoration.

The UN Decade programme also supports the implementation of 17 Sustainable Development Goals (SDGs), and other conventions and targets related to climate change, desertification, biodiversity as well as other landscape restoration projects (Fig 2).

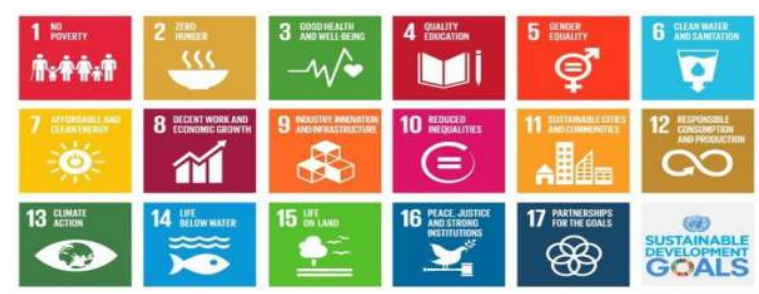

Fig 2. The 17 Sustainable Development Goals (SDGs). 
- Eliminate Poverty

- Erase Hunger

- Establish Good Health and Well-Being

- Provide Quality Education

- Enforce Gender Equality

- Improve Clean Water and Sanitation

- Grow Affordable and Clean Energy

- Create Decent Work and Economic Growth

- Increase Industry, Innovation, and Infrastructure

- Reduce Inequality

- Mobilize Sustainable Cities and Communities

- Influence Responsible Consumption and Production

- Organize Climate Action

- Develop Life Below Water

- Advance Life On Land

- Guarantee Peace, Justice, and Strong Institutions

- Build Partnerships for the Goals

\section{TYPES OF WORLD'S ECOSYSTEM}

The programme has categorized eight vital earth's ecosystem for restoration, they are: farmlands, forests, freshwaters, grasslands, shrublands and savannahs, mountains, oceans and coasts, peatlands and urban areas.

\section{* Farmlands}

Farmlands endure human life imparts with food, fiber and other essential products and supplement of biodiversity habitat, economic opportunities and spiritual and cultural benefits (UNCCD, 2017). At least two billion people depend on the agricultural sector for their livelihoods, particularly poor and rural populations, and over $90 \%$ of calories and protein originate on farmland degradation is reducing crop and livestock yields (Searchinger et al., 2019; Abraham and Pingali, 2020; FAOSTAT, 2021). While farmland degradation typically involves harm to soils, it can also result from the loss of wild species that provide pest control and crop pollination (FAO and ITPS, 2015; Dainese et al., 2019). Roughly $80 \%$ of global arable land is impacted by at least one form of degradation, such as aridity, vegetation decline, soil salinization and loss of soil carbon which affects roughly one-fifth of farmlands worldwide.

\section{* Forests}

Forests helps in the regulation of climate and absorption of carbon from the atmosphere; which provide habitats for $80 \%, 75 \%$ and $68 \%$ of all amphibian, bird and mammal species, respectively (Vie et al., 2009; Harris et al. 2021). They contribute to precipitation, regulate stream flow and foster groundwater recharge, providing drinking water to one-third of the world's largest cities (HLPE, 2017). Food, shelter, energy, medicines and around associated jobs come from forest products (FAO, 2014; 2018). Nearly 100 million hectares of tropical forests were converted to farmland. Apart from fragmentation, hunting it also accelerated the loss of biodiversity from these ecosystems. Although deforestation has slowed in recent years, the world lost around 10 million hectares of forests per year between 2015 and 2020 (FAO and UNEP, 2020). Each year on an average of 122 million hectares of forests are affected by fires, pests, diseases, invasive species, drought and adverse weather events. Degradation could affect up to 1.75 billion people who live in or near forests, including indigenous and local communities, small holders and people who work in formal or informal forest-based enterprises by the increase of the risk of flooding and, along with fragmentation of ecosystems, increases human-wildlife conflicts (Gibb et al., 2020). It has been linked to outbreaks of vector-borne diseases like malaria (Morand and Lajaunie, 2021) and animalborne diseases, such as COVID-19 (UNEP and ILRI, 2020) and Ebola (Olivero, 2017). According to FRA 2020 , forests currently cover $30.8 \%$ of the global land area where more than half of the world's forests are found in only five countries (the Russian Federation, Brazil, Canada, the United States of America and China) and two-thirds (66\%) of forests are found in ten countries.

\section{* Freshwater}

Freshwater bodies are home to around one-third of vertebrate species and $10 \%$ of all described species on Earth with many more in the world's wetlands. Freshwater ecosystems provide food through inland fisheries, water for drinking, agriculture and industry, and transportation of goods (Funge-Smith and Bennet 2019; CBD, 2020b). They help in the regulation of water quality and regional climate and provide flood protection. Forests and water are interlinked, with an estimated $75 \%$ of the world's accessible freshwater coming from forested watersheds (FAO, 2019). 
Approximately 1.4 billion livelihoods worldwide are directly reliant on water, including jobs related to the food and beverage, energy and water industries (UN, 2018). The integrity of freshwater ecosystems - and their capacity to provide ecosystem services - is increasingly under threat. Use of freshwater for power generation and irrigation provides economic benefits, but it can also cause environmental and socioeconomic impacts downstream (Snoussi et al. 2007). Agriculture accounts for $92 \%$ of the global freshwater foot print, and $29 \%$ of the water in agriculture is directly or indirectly used for animal production (Hoekstra and Mekonnen, 2012). Freshwater ecosystem degradation and over-abstraction are contributing to water scarcity; half a billion people worldwide face severe water scarcity year round (Mekonnen and Hoekstra, 2016).

\section{* Grasslands, Shrublands and Savannahs}

Most grasslands, shrublands and savannahs are found in drylands, although some are cool and wet, occurring in continent but most extensively in Africa and Asia, drylands also include hyper-arid deserts ((Prăvălie, 2016; UNCCD, 2017). Drylands generally have a low productivity, yet they support the livelihoods of over 1.75 billion people, including many poor populations (Safriel et al., 2005; Mortimore, 2009). Over 250 million people depend on drylands for their livelihoods in East Africa. Collectively they store substantial soil organic carbon, helping to mitigate climate change (Mbaabu et al., 2020). They also provide water storage and regulation, wood fuel, timber and charcoal, as well as forage for livestock. Agriculture has globally cleared and/or transformed an estimated $70 \%$ of grasslands; and $50 \%$ of savannahs (Foley, 2011). Degradation of grasslands and savannahs threatens the culture and livelihoods of indigenous and ethnic minority communities (Dudley et al., 2020).

\section{* Mountains}

Mountain ecosystems host roughly half of the world's biodiversity hotspots and support the livelihoods of people living in mountain regions and provide critical ecosystem services to inhabitants of lower lands, including freshwater, timber and recreation opportunities (CBD, 2007). Known as the 'water towers of the world', mountain ecosystems fulfill the freshwater needs of half the global population (CBD, 2007; UNEP, Grid-Arendal, GMBA, 2020). Mountains are also a source of food: of the 20 plant species that supply $80 \%$ of the world's food, six-maize, potatoes, barley, sorghum, tomatoes and apples - originated from and have been diversified in mountains (UN, 2020b). Degradation of mountain ecosystems is endangering crop production, animal husbandry and overall food security (Romeo et al., 2020). Globally, 311 million people, approximately half of the mountain population in developing countries, live in areas exposed to progressive land degradation. Of these, 178 million are considered vulnerable to food insecurity. Changes in snow and glaciers affect run-off in some river basins, in turn impacting local water resources and agriculture (Hock et al., 2019).

\section{* Oceans and coasts}

The ocean sustains all life on Earth and provides the world's life-supporting space and oxygen in the atmosphere. It regulates our weather and climate, provides food and medicine and holds sacred and intrinsic value for many indigenous and local communities. Salt marshes, coral reefs, sea grass beds and mangroves protect coastlines by slowing floodwater release and reducing wave heights (Das and Vincent, 2009; Shepard et al., 2011; Ferrario et al., 2014; UNEP, 2016).Yet a third of our oceans' commercial fish stocks are now overfished (FAO, 2016b; 2020b). This threatens the livelihoods of fishers, of which there are 60 million globally (FAO, 2020b). Plastic pollution is estimated to reduce marine ecosystem services (Beaumont et al. 2019). Microplastics, and their toxic chemicals, are present in seafood and drinking water (UNEP 2019a). Over the last 50 years, the open ocean has lost 77 billion metric tonnes of oxygen, expanding 'dead zones' by 4.5 million $\mathrm{km}^{2}$ - similar in size to the European Union (Stramma et al., 2010; Schmidtko et al., 2017). Rising water temperatures and acidification (caused by rising CO2 levels) are affecting the productivity and the distribution of marine fish stocks (FAO, 2020b). Unless we make drastic cuts to greenhouse gas (GHG) emissions, all coral reefs worldwide are expected to disappear due to bleaching and acidification by the end of this century (UNEP, 2017). Coastal development and conversion to aquaculture have led to the loss of 20 $\%$ of the world's mangroves, along with their protective services (Friess et al., 2019; UNEP, 2014). Almost 30\% of all seagrass has been lost since the late 19th century (UNEP, 2020a).

\section{* Peatlands}

Peatlands store nearly $30 \%$ of global soil carbon despite covering only $3 \%$ of the world's land area 
(Joosten, 2009; Scharlemann et al., 2014). They purify and supply water, offer a natural haven for culture and recreation, and provide biomass, food and other livelihoods to millions of people (Crump 2017). Many European countries have drained the majority of their peatlands, including Germany (98\%), The Netherlands (95\%), Denmark (93\%), and Ireland (82\%) (Tanneberger et al., 2017). Drainage, which affects nearly $15 \%$ of all peatlands, leads to subsidence (sinking), land loss, vulnerability to toxic hazeproducing fires and, in coastal peatlands, salinization (Crump 2017; FAO 2020a). It also contributes to peatland degradation, which accounts for 3-4\% of all global GHG emissions each year (IPCC, 2014; Leifeld and Menichetti, 2018; Olivier and Peters, 2019). In the tropics, drainage is mainly associated with commodity plantations, such as oil palm cultivation, as well as acacia (IPBES, 2018; Evans et al., 2019). Restoring peatlands could avoid GHG emissions equivalent to $12-41 \%$ of the remaining GHG budget for keeping global warming below $2^{\circ} \mathrm{C}$ (Leifeld et al., 2019).

\section{* Urban areas}

Urbanization is the process through which cities grow and higher and higher percentages of the population comes to live in the city. Cities can play a key role in increasing standards of living and decreasing poverty and, if well-managed, provide good homes, opportunities for social interaction, clean air and water, food and climate regulation. In addition to climate regulation, green and blue infrastructure contributes to water regulation and pollution reduction, as well as enhancing human well-being (Elmqvist et al., 2015). Cities can also harbour significant biodiversity in urban parks, gardens and restored landscapes such as industrial parks, railway tracks and residential areas (CBD, 2021). However, ineffective urban planning and management have contributed to socioeconomic inequality and deteriorating environmental quality. Although access to water and sanitation is usually better in urban areas than rural ones, the number of city inhabitants without access to safely managed drinking water has increased by more than 50\% since 2000 (UN Water, 2021). According to estimates, cities generate $70 \%$ of global carbon emissions and consume two-thirds of the world's energy (UN Habitat, 2020). Air pollution is a major health risk: more than $80 \%$ of people living in urban areas that monitor air pollution are exposed to air quality levels exceeding World Health Organization guidelines (UN, 2016).

\section{ECOSYSTEM RESTORATION IN INDIA}

India is one of the mega biodiverse countries with only $2.4 \%$ of the world's land area where $7-8 \%$ of all species are recorded including 45,000 species of plants and 91,000 species of animals. India hosts $8.6 \%$ of all mammalian, $13.7 \%$ of all avian, $7.9 \%$ of all reptilian, $6 \%$ of all amphibian, $12.2 \%$ of all piscine, and $6 \%$ of all flowering plant species. Approximately $28 \%$ of the total Indian flora is endemic.

India is holding four of the world's biodiversity hotspots: The Himalayas, The Western Ghats, The North-East, The Andaman-Nicobar Islands. Between these, lie the moist deciduous Sal forest of eastern India, the dry deciduous Teak forest of central and southern India, and the Babul dominated thorn forest of the central Deccan and western Gangetic plain. Approximately $24.16 \%$ of the country's geographical area is under green cover.

However, India is also the second most populous country in the world and a sizeable portion of the country's population is heavily dependent on resources and services provided by the natural ecosystems. The country's forests, grasslands, coasts and other ecosystems are now increasingly threatened with deforestation, degradation, fragmentation and other anthropogenic habitat modifications. Addressing and reversing the negative impacts of unplanned growth and development can be achieved by adopting the forest landscape restoration approach. An area of approximately 108 million hectares would need to be brought under green cover. Presently, the forest and tree cover of India is $24.16 \%$ or 79.42 million hectares according to the India State of Forest Report (ISFR) 2015. This further classifies the forests into 2.61\% Very Dense forest (more than 70\% canopy cover), 9.59\% Moderately Dense forest (40-70\% Canopy cover), and $9.14 \%$ Open forest (10-40\% canopy density) (Fig 3).
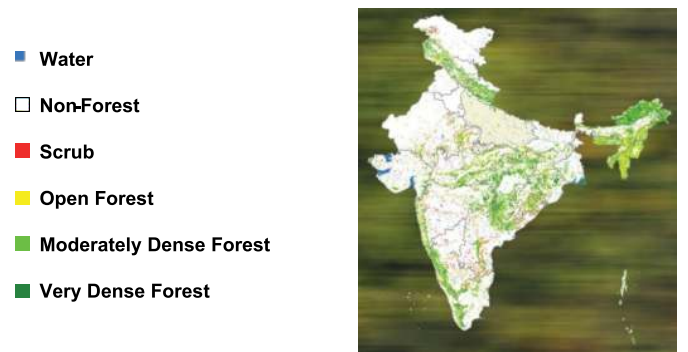

Fig 3: Geographical distribution of Indian Forest (Source:Binod et al., 2018), 


\section{* Focus on Ecosystem Restoration beyond conservation}

Ecological restoration is still a developing discipline in India, with a limited number of practitioners and projects. Most initiatives are small and site-specific. On the other hand, the need for restoration is considerable and urgent.

More importantly, restoration has the capacity to generate substantial rural livelihoods and reduce human-wildlife conflicts. India has an ambitious target of restoring 26 million hectares of degraded lands by 2030. Reaching this target will require certain key enablers to be in place.

1) Restoration ecology has a rather low presence in academic curriculum in India at present and this needs attention. Separate processes will also be required for the training of field-level staff who will conduct implementation and monitoring programmes.

2) To make sure that projects adhere to the core principles of restoration. The international standards can help in this regard, with suitable adaptation for Indian conditions.

3) A typical restoration project lasts well over fivesix years, and calls for sustained funding and focus. These enablers will make the difference between successful restoration and otherwise.

\section{SOME OF THE LEARNINGS OF RESTORATION INITIATIVES:}

In Jim Corbett National Park, Uttarakhand: Lantana (Lantana camara), one of the world's most troublesome invasive weeds, has become a menace in most of the protected areas located in tropical and subtropical belt of India. The lantana-infested landscapes not only are impoverished as habitats of wildlife but also contribute to human-wildlife conflicts owing to diminished ecosystem services. It is a small case of study of successful eradication and restoration of two lantana-invaded sites in Jim Corbett National Park, India. The idea of eradicating lantana developed using knowledge about its ecology. Subsequently weed free landscapes were restored to productive grasslands and mixed woodlands using native species. It has enhanced the habitat quality for herbivores whose populations are vital for the survival of top carnivores such as tiger (Panthera tigris corbetti). The restoration of these areas to grassland communities has successfully prevented secondary invasions by lantana and other weeds.

* In Old Jalukie, Nagaland: Old Jalukie is located in the north-eastern part of the country, Old Jalukie is a village in Nagaland, India. The village falls within an important watershed area. In the absence of schemes that provide alternate livelihood opportunities, farming is performed by slashing and burning the forests, an old technique called jhum, where the land is often left fallow for its recovery. The village council declared an area of 370hectares as Community Biodiversity Reserve and agreed to impose a total ban on jhum cultivation, hunting, logging and tree felling within the declared area. Fallow lands were afforested using locally available species that can be used in construction and are commercially viable. A total of 291 hectares was planted using saplings that were germinated from seeds collected from the nearby forests. The combined efforts of the local community along with JFMC have had a positive impact on the ecosystems of Old Jalukie. Abiotic properties of the area like soil quality and water availability have also seen considerable improvement. Old Jalukie, having won the India Biodiversity Award 2014 and Governor's Award 2014, serves as a model JFMC.

In Lonavala, Maharashtra: Lonavala, situated in Maharashtra, India is part of the global "biodiversity hotspot”, the Western Ghats. Lonavala's growing popularity as a site for both tourism and developmental projects such as construction of roads, railways, industries supplemented by an ever increasing population has negatively impacted surrounding forest landscape. The company targeted to achieve a minimum of $33 \%$ forest cover in all project sites through plantation of native trees by employing local villagers. Special efforts were made to protect the endangered Golden Mahseer fish in the local lakes and rivers. To make the restoration process sustainable and community driven, Tata Power also organized awareness campaigns among villagers. However, only $30 \%$ of the planted saplings survived in the unprotected areas due to cattle grazing and uncontrolled fire, while thesurvival rate in the protected areas was around $80 \%$. Wildlife habitats were restored gradually and corridors were created to assist their move. The increased productivity of the forests meant the villagers now had more fodder, fuel wood and other forest products. Tata Power's 
restoration activities in Lonavala, owing to increased community involvement, have proven to ecologically and socially effective.

> In Valparai, Tamil Nadu: Valparai, a hill station in the southern State of Tamil Nadu, is part of the Anaimalai Hill range of the Western Ghats. The rainforest restoration programme was started by Nature Conservation Foundation in collaboration with Hindustan Unilever Limited (HUL) to conserve the biodiversity in the forest fragments present in the company owned land within the landscape. NCF carried out the restoration process meticulously, following scientific methods. After plots were chosen, a reference system based on the intact forests in the landscape was selected. The removal of Lantana camara and other invasive species contributed towards a high survival rate of native saplings. NCF reported that $70 \%$ of the planted saplings survive. Active intervention measures such as weeding out invasive species helped protect the native species. It will create corridors for wildlife movement and habitat patches for vulnerable species, increase carbon sequestration, improve soil and water conservation (Fig 4).
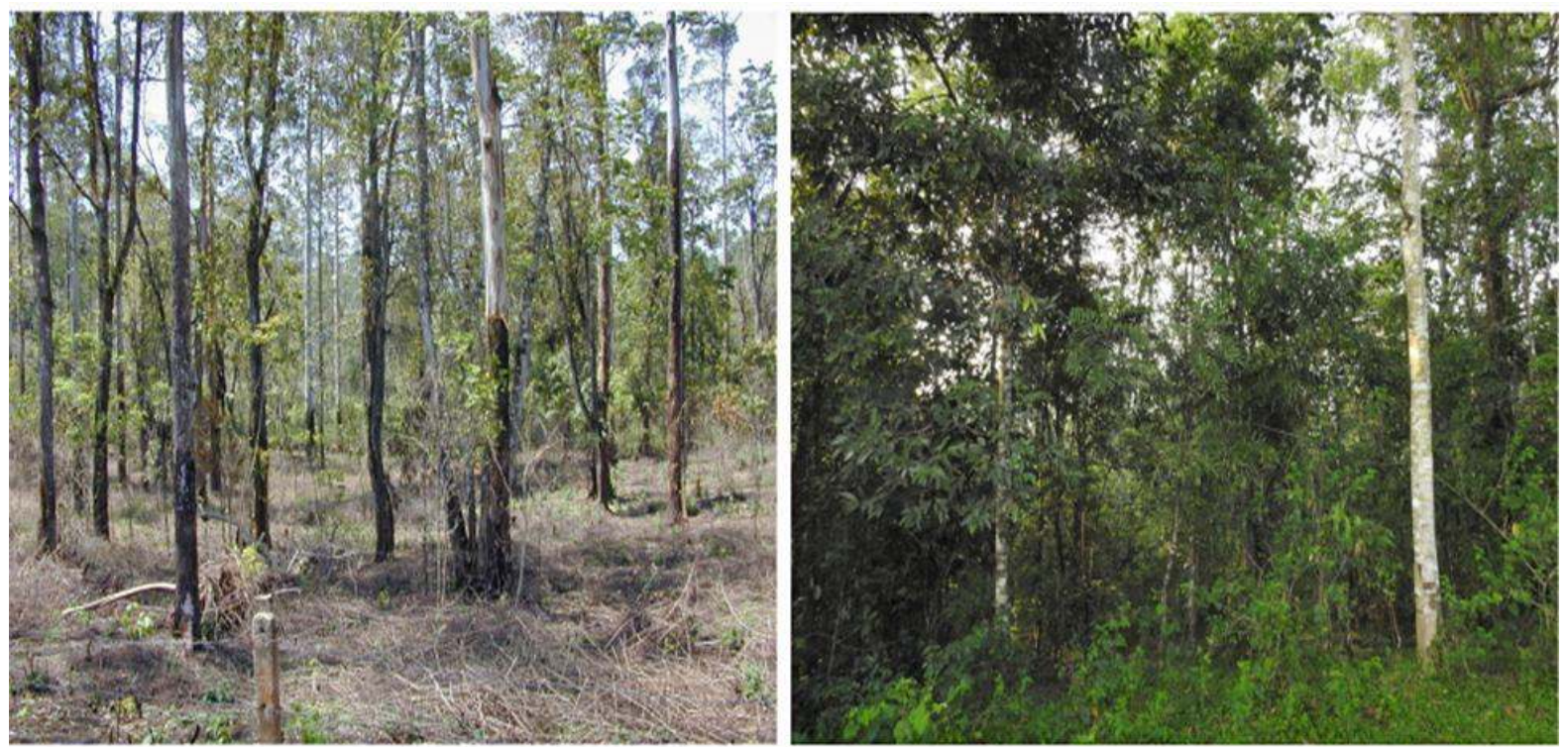

Fig 4: In the Anaimalai hills, preparation for restoration planting in 2004 (Left) and some recovery shows of rainforest trees in 2018 (Right)

[Source: https://www.conservationindia.org/articles/rainforest-fragments]

In Andhra Pradesh; Odisha; Madhya Pradesh: Restoration initiatives by Foundation for Ecological Security (FES) spanning thirty years across three Indian States were selected as best practices. These included the following sites: Thamballapalle and Peddamandyam in Andhra Pradesh; Angul, Dhenkanal, Koraput and Keonjhar in Odisha; Indravan, Mandla and Agar in Madhya Pradesh. All sites in Madhya Pradesh reported invasion by Lantana camara, an exotic species that thrives well under disturbances, and causes changes to local soil and moisture properties apart from altering native plant communities. Sites in Andhra Pradesh reported higher frequencies of fires that damage wild vegetation and planted crops. Thus, forest degradation in these areas triggered a complex series of reactions, impacting biodiversity, ecological processes and the local people. In total; 1,002,446 hectares of forest land was restored of which 30,856 hectares belonged to sites from Madhya Pradesh, 632,413 hectares were from Odisha and 339,197 hectares belonged to sites from Andhra Pradesh. Sites were regularly monitored with the aid of local villagers. Survival rate of saplings from all sites across three States was reported to be nearly $70 \%$. As forest productivity improved and villagers gained more access to fodder, fuel wood and NTFPs, their livelihood was enhanced. These economic benefits managed to bring about a change in the perception towards restoration activities. FES advocates the consultation of local bodies to ensure that restoration efforts help to regain productivity, revive ecological 
processes and ensure the wellbeing of both man and biodiversity.

> In Banni, Gujarat: In India, 24\% of the geographical area is covered by grasslands. Grasslands support a wide variety of browsers and grazers, and the predators that depend on them. Declared a protected forest in 1995, Banni grassland covers about $11.71 \%$ of the mainland area of Kutch district in Gujarat. It is a dry savannah type grassland interspersed with wetlands in low lying areas, with vegetation dominated by grass species and a rich community of flora and fauna. Apart from changing vegetation composition, it has led to the loss of many wetlands as well as the disappearance of winter migrating wetland birds. The livestock is now concentrated in small pockets, causing additional pressure on the grassland. Banni by including members from the local communities in all aspects of restoration. GUIDE along with the Forest Department, held meetings to discuss restoration plans with village heads and other local villagers. To understand the success rate of the restorative efforts, monitoring was undertaken for the developed grass plots and areas under restoration. For Banni grasslands to recover from the damages caused in the past, restoration practices must continue to be implemented with a community centric approach.

> In Sundarbans, West Bengal: A new technology developed by Indian scientists for ecological restoration is helping in revival of mangroves degraded due to rising sea levels, climate change and human intrusion in the Sundarbans in West Bengal. Ecological restoration refers process of assisting the recovery of an ecosystem that has been degraded, damaged or destroyed as a means of sustaining ecosystem resilience and conversing biodiversity. The restoration technology, developed by Krishna Ray (West Bengal State University, Kolkata) and Sandip Kumar Basak (Sarat Centenary College, Dhaniakhali), involves plantation of native salt-tolerant grasses and a diverse set of carefully identified mangrove species in different zones of degraded mangrove patches. The Sundarbans is a protected wetland under the Ramsar Convention and is also a UNESCO World Heritage site. Small coastal patches of mangroves are highly vulnerable and fragmentation of the ecosystem is creating barriers to species movement and dispersal. The restoration method has been tested on a two-hectare degraded patch of mangroves in Ramganga village over the past five years and has been found more effective than monoculture of mangrove plantations as usually practiced. The project was initiated with help from the Department of
Biotechnology in 2013 and is now likely to be extended to 100 acres. The transplantation started in November 2014, initially at a moderately degraded patch and was then extended to severely degraded zones (Fig 5). The restoration process begins with stabilizing entire site of restoration by planting native salt tolerant grasses. An onsite mangrove nursery was developed to propagate mangroves for transplantation. Besides local mangroves and associate species, the nursery also grew threatened, endangered and vulnerable species. In all, 22 species of mangroves and associate plants were grown so as to maintain native diversity.

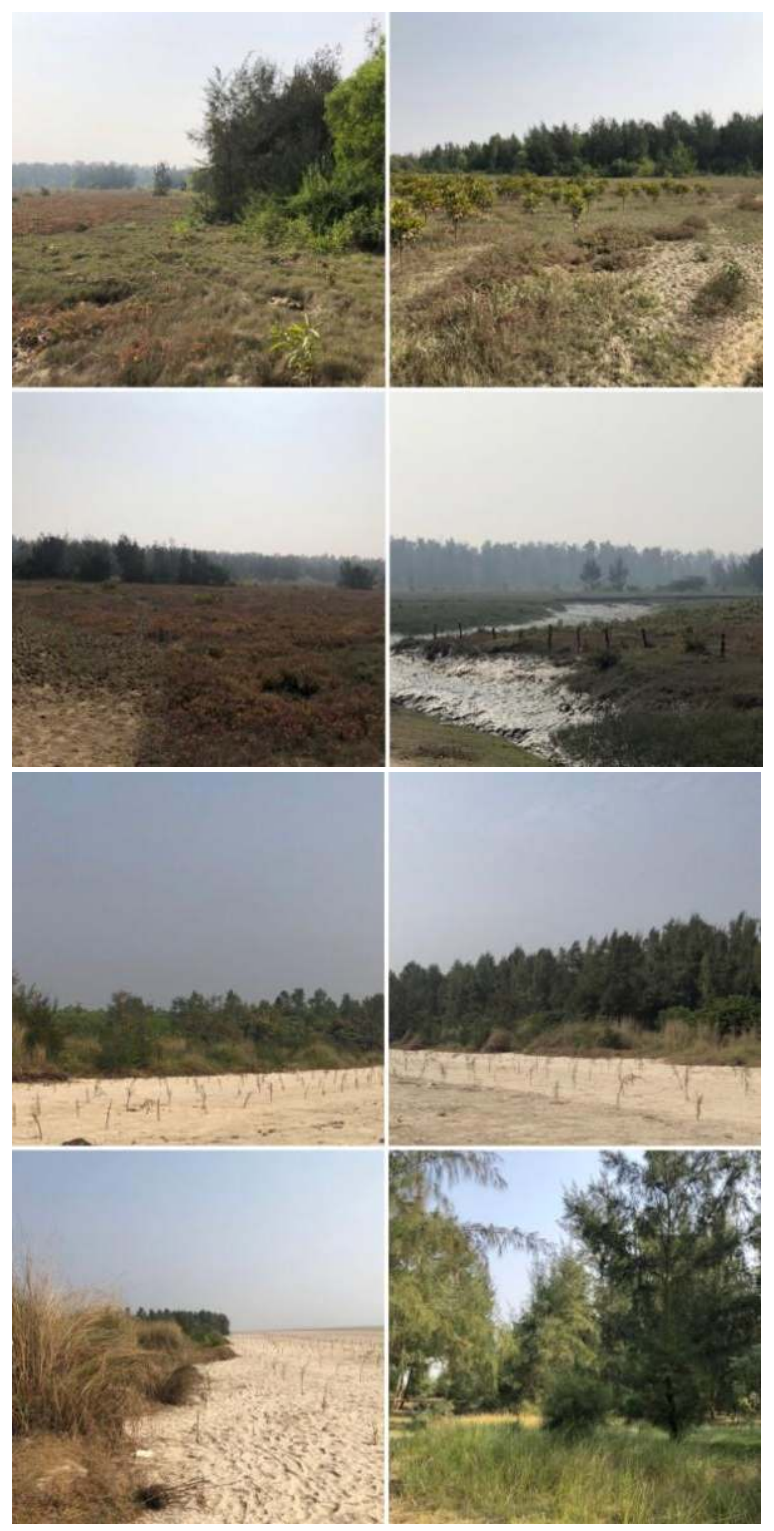

Fig 5. Ecological restorations in coastal Sundarbans, West Bengal. Photo credit: S. K. Basu 
> In Western Ghats: The effectiveness of forest restoration in the Western Ghats, shows significant recovery of tree cover and plant biodiversity. Controlled active restoration, performed by planting native species and eliminating weeds, can also aid carbon sequestration, the study has found. The researchers conducted their study on the Valparai Plateau, a 22,000-hectare section of the Anamalai Hills, which they describe as a "human-modified landscape”. The region has witnessed extensive deforestation between 1890 and 1940 for tea, coffee, cardamom, and eucalyptus plantation by the British. Remnants of the rainforest were used for selective timber felling in the past. Since 2000, three plantation companies have conducted restoration activities on the plateau. The sites were carefully chosen after ensuring they were degraded rainforests alone and didn't include the famously misunderstood native grasslands of the Western Ghats. The active restoration process included steps to prevent cutting of wood, preventing the growth of weeds, and planting a diverse variety of native species. Researchers studied an average of 1,099 plants, spanning 106 species, per hectare and 50 plots of land in the region, half of which underwent 'active restoration', while the other half underwent 'natural regeneration' where nature took over with no human intervention. Before and after photographs helped compare tree cover, and the sites were studied in pairs. A key strength and distinguishing feature of the study is the examination of multiple components of ecosystem recovery, from canopy closure and the diversity of tree species, to the amount of carbon sequestered, in restored forest. The team discovered that active restoration came closer to the natural ecosystem and healthy growth of the benchmark areas. Compared to natural regeneration, these plots also showed more consistent and prominent results.

> In Nilgiri Biosphere Reserve: To cite a simple example, over $50 \%$ of protected areas in the Nilgiri Biosphere are invaded by alien plant species, severely impairing biodiversity and availability of fodder for herbivores. And accentuating human-wildlife conflict. Dry and moist deciduous forests have been degraded by species like Lantana camara, Chromolaena odorata and Parthenium hysterophorus. New threats like Senna spectabilis are expanding aggressively. Shola-grassland ecosystems in the upper Nilgiris that form crucial watersheds have been impacted by species like Acacia mearnsii (Black Wattle) amongst others. At a back of the envelope calculation, this means over 2500 sq. kms of degraded area in NBR alone. This would need restoration action at a very large scale for the next thirty to forty years. If implemented well, this could significantly increase the carrying capacity of our ecosystems for wildlife.

\section{SOME OF THE ECOLOGICAL RESTORATION PROJECTS AIMING TO HEAL THE WORLD}

> Bamboo and Agroforestry for land restoration:

i. Planting bamboo both enhances land vitality and supplements the income of local people. These benefits were documented in Anji, China, where bamboo shoots were valued at approximately USD 2 billion per year (INBAR, 2018). In Tanzania, bamboorelated enterprises generated an estimated extra USD 200 every month for each household and created jobs for nearly 1000 villagers (FAO and INBAR 2018). China, Ethiopia, Cameroon, Viet Nam, India, Madagascar, Ghana, the Philippines and Kenya are other countries that have successfully incorporated the use of bamboo for land restoration (FAO and INBAR, 2018). Peprah et al. (2014) demonstrated the ability of bamboo to restore degraded lands in Ghana, reporting overall survival rates of $95 \downarrow \%$ and rapid foliage growth converting degraded sites into green landscapes.

ii. Another successful example of plant-based land restoration is agroforestry. Agroforestry is often suitable for landscape restoration, it can improve soil properties, resulting in increased soil fertility and erosion and improved water availability to plants. Agro-forestry can improve rural livelihoods by providing a variety of products, including food, fodder, fibre and wood. Selecting appropriate species for the local soil and climate conditions is critical for the success of agro-forestry systems. For example, Lu et al. (2017) and Bohre and Chaubey (2014) recommend very differ sets of species for subtropical forest restoration in Southwest China, and land restoration of Northern Coalfield Limited in Singrauli, Uttar Pradesh, India, respectively. The use of bioenergy plants for degraded land restoration is gaining worldwide attention as it provides multiple benefits in the form of firewood, biodiesel, bioethanol, charcoal, plywood, paper, pulp, and so on (Tripathi et al., 2017). Commercial utilization of these end products also helps in fostering a bio-based economy and reducing poverty by providing a market for products that can often be produced on both degraded and restored land. 


\section{$>$ In Costa Rica Water Fund}

Agua Tica is the first public-private water fund initiative in Costa Rica. Its target is to restore and conserve forests in a critical watershed near the Greater Metropolitan Area of the capital city, San Jose, in order to achieve water security by maintaining high quality water for downstream users. This area is key to the country's water supply with nearly $60 \%$ of its population (2.6 million inhabitants) and $70 \%$ of its industry located in the watershed. As a consequence, demand for water is high as a result of population growth, historic scarcity and changing land use. Before watershed protection, deforestation to establish agriculture and grazing was rapid, and was causing increased erosion and degraded water quality. The water fund project operated by The Nature Conservancy (a Costa Rican NGO) and other partners; offer protection to the inland riverine forest areas and native cloud mountain forests. Agua Tica is based on the premise that preserving water quality and quantity will provide economic, environmental and social benefits. In the 1970s and 80s, this region of Costa Rica had one of the highest rates of deforestation globally (the Natural Capital Project), which led to soil erosion, nutrient run-off and unhealthy water quality. In a payment for ecosystem services scheme, landowners in the watersheds that are the source of water supplies are paid to plant trees, build fences to keep cattle out of riverbeds, and sustainably manage their forests. The anticipated benefits of the project include erosion control to maintain the quality of drinking water supplies, the protection of reservoirs, improved ground water recharge, and improved dry season flows to secure reliable water supplies. Specific activities that contribute to reaching these goals include investment in forest protection, adoption of agricultural best practices, environmental education, and establishment of agro-forestry systems, embankment control, and reforestation. The programme is also tracking the mitigation of greenhouse gas releases and biodiversity conservation.

\section{$>$ Mexico's National Forestry Commission}

Mexico's National Forestry Commission (CONAFOR) successfully restored 1 million hectares of forest land throughout the country, between 2014 and 2018, according to Initiative20x20. CONAFOR worked with local landowners and communities to help them implement restoration projects, and the plant survival rate in the region has nearly doubled.
The World Resources Institute has praised CONAFOR's work, calling it "exactly the right way to show leadership on restoration in Latin America.” The program remains active, and is continuing to work with residents on planting trees that will provide economic benefits as well as improving the country's resilience to climate change.

\section{$>$ Coastal development and coral reef degradation}

Waikiki, Hawaii, demonstrates how land-use change and degradation can impinge on coral ecosystems. The image shows how terrestrial habitats that would contribute to the resilience of coral reefs have been replaced by urban and tourism infrastructure. It also shows how areas of reef have been removed entirely and replaced by recreational marinas, including a channel cut through the reef to enable boats to reach the shore. Although opportunities for coastal habitat and reef restoration appear limited, efforts are being made to reduce the stressors affecting Hawaii's reefs from land-based activities. For example, in May 2018, Hawaii became the first state of the United States of America to pass a law (which will come into effect in January 2021) to ban sunscreens containing oxybenzone and octinoxate, which have been found to be harmful to coral reefs (Coldwell 2018).

\section{$>$ Dune restoration for protecting urban area}

In 2012, after a major coastal storm which destroyed beach-dune support infrastructure, Almada municipality decided to undertake sand fore-dune restoration with the ReDuna project. Along $1 \mathrm{~km}$ of the Atlantic coast, support structures and native species were used to restore the ecosystem. The facilities installed, such as overhanging walkways and signage, have enhanced the possibilities of the local population and tourists for interacting with sand dunes and getting to know their value and importance, while reducing trampling. This project is praised by the local population and tourists for providing added aesthetic values and by beach support-structure owners, who were able to keep the economic revenue from the facilities. Over time, native vegetation and animals have returned, increasing biodiversity and providing resilience to the restored ecosystem.

\section{In Brazil land restoration}

The semi-arid region of Brazil located in the Caatingaand Minas Gerais (about 858,000 $\mathrm{km}^{2}$ ) is susceptible to land degradation and is home to $29 \%$ of 
the country's population, including the poorest of the region, with quality of life below the national average. Land degradation intensified by drought is one of the most serious environmental problems of this region, causing significant economic and social damages. The National Policy to Combat Desertification and Mitigate the Effects of Drought (adopted in 2015) recommends that states and municipalities mainstream actions into their public policy to address this problem. To this end, the Department of Sustainable Rural Development and Combating Desertification is working with municipalities of the region in the planning and implementation of the URAD project (Recovery Units of Degraded Areas and Reduction of Climate Vulnerability) through environmental, social, and productivity initiatives underpinned by the mix of six activities: training and capacity building of rural smallholder farmers; rehabilitation and conservation of soils; water and biodiversity; water harvesting; basic sanitation; and energy efficiency. The programme anticipates engaging families living in the recovery units in the implementation of actions such as the construction of dams, ecological stoves, beekeeping, and the rehabilitation of riparian forest, so that the community takes ownership of technology to improve quality of life, increase employment and income and food security.

\section{$>$ Maiden Island Reef}

The reefs around Maiden Island in the Caribbean were the subject of what the Society for Ecological Restoration refers to as the "the world's largest total marine ecosystem restoration, which included both coral reef and mangrove habitats." Part of the reef had been destroyed by Hurricane Luis in 1995, and the reef had also been degraded by urbanization and industrialization. The restoration used thousands of Reef Balls, an "artificial reef module which mimics the structure and function of a natural reef.” Corals were attached to the reef balls, ultimately resulting in 5,000 new coral colonies consisting of more than 30 species.

\footnotetext{
ABOUT RESTORING ECOSYSTEMS

One hundred and fifteen governments have committed to restoring a total of around 1 billion hectares on land, as a contribution to achieving the objectives of the CBD, UNCCD, UNFCCC or the Bonn Challenge on forest landscape restoration (Keeble, 2015; Sewell et al., 2020). The roots of degradation lie within our economic and political systems; the solution will be neither quick nor easy. It outlines insights from a
}

growing body of research that is establishing the principles of successful restoration, as well as technical and scientific innovations to facilitate the work.

\section{A. Approaches and Principles for Restoration Programmes}

Ecosystem restoration encompasses a wide variety of approaches that contribute to conserving and repairing damaged ecosystems (UNEP and FAO, 2020). This may involve active restoration or the removal of drivers of degradation to 'passively' promote natural regeneration. Whatever the approach, restoration requires time, resources, knowledge, enabling policies and governance if it is to contribute to human wellbeing, economic development, climate stability and biodiversity conservation.

\section{* Restoration approaches}

\section{ECOLOGICALRESTORATION}

1) Process - Assisting the recovery of a terrestrial, freshwater or marine ecosystem that has been degraded, damaged, or destroyed.

2) Intended end point - Transition from degraded ecosystem to a reference ecosystem, which may be a natural or a cultural one.

\section{$>$ FOREST AND LANDSCAPE} RESTORATION

1) Process - Reversing the degradation of soils, agricultural areas, forests and watersheds thereby regaining their ecological functionality

2) Intended end point - Restoring multiple ecological, social and economic functions across a landscape and generating a range of ecosystem goods and services that benefit multiple stakeholder groups.

\section{$>$ RESTORATION OF AQUATIC} PRODUCTION ECOSYSTEMS

1) Process - Maintaining ecosystem structure and function to support food provisioning, while minimizing impacts, rather than restoring ecosystems to an initial state before production activity started.

2) Intended end point - Large oceanic marine ecosystems supporting or affected by direct and indirect impacts of fishing gears and fisheries 
production; recovery through changes in fishing methods and gear modification to rebuild fish stocks and reduce adverse impacts on the environment. Specificities shown for both freshwater ecosystems and coastal ones with linkages to fisheries and aquaculture.

\section{REGENERATIVE AGRICULTURE}

1) Process - Farming that uses soil conservation as the entry point to regenerate and contribute to multiple provisioning, regulating and supporting services.

2) Intended end point - Enhancing environmental, social and economic dimensions of sustainable food production. Soil carbon, soil health and onfarm biodiversity are restored.

\section{$>$ REWILDING}

1) Process - Rebuilding, following major human disturbance, a natural ecosystem by restoring natural processes and the complete or near complete food-web at all trophic levels as a selfsustaining and resilient ecosystem using biota that would have been present had the disturbance not occurred.

2) Intended end point - No pre-defined end point. Functioning native ecosystems complete with fully occupied trophic levels that are nature-led across a range of landscape scales.

\section{* Restoration principles}

The Strategy of the UN Decade on Restoration calls for the development and implementation of genderresponsive methods for empowering women and girls in dialogue, planning, decision-making and implementation of ecosystem restoration (UNEP and FAO, 2020).

International Principles: Present a robust framework to guide restoration project toward achieving intended goals. It highlights the role of ecological restoration project is connecting, productivity and sustainability goals. It recommends performance measures for restoration activities for industries, communities and governments to consider. The Standards support development of ecological restoration plans, contracts, consent conditions, and monitoring and auditing criteria. Generic in nature, in standards framework can be adapted to particular ecosystems, biomes or landscapes; or traditional cultures. The standards provide a blueprint for ensuring ecological restoration achieves its full potential in delivering social and, ultimately, long-lasting economic benefits and outcomes. Such principles can help to address challenges in restoration, including effective design and implementation, accounting for complex ecosystem dynamics in the context of climate change and navigating trade-offs associated with land management priorities and decisions (Gann et al., 2019) (Fig 6).

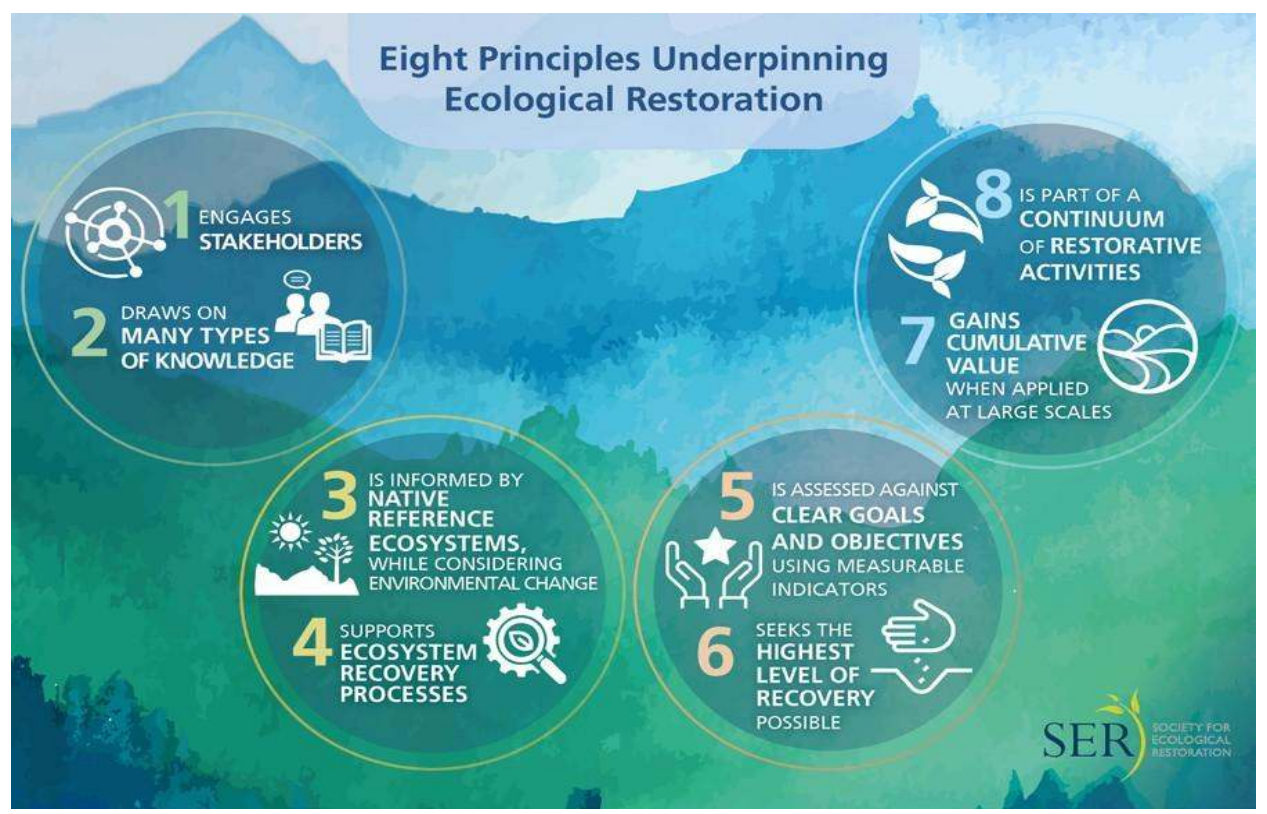

Fig 6: Eight principles underpinning Ecological Restoration(Gann and McDonal, 2019). 


\section{Key principles to guide Ecological restoration}

\section{PRINCIPLE 1}

\section{ENGAGES STAKEHOLDERS}

The interests and contributions of multiple stakeholders, especially of the local ones are identified, regarded and directly involved by the Ecological Revival projects to render advantages to both human beings and nature (Fig 7).

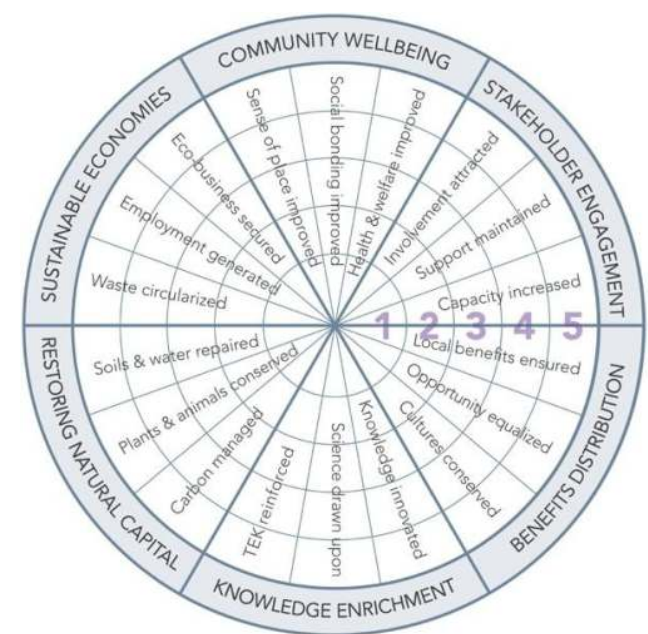

Fig 7: A Social Benefits Wheel(Gann and McDonald, 2019).

\section{PRINCIPLE 2}

\section{$>$ DRAWS ON MANY TYPES OF} KNOWLEDGE

The amalgamation of obtained practitioner knowledge, conventional ecological knowledge, local ecological comprehension and scientific unearthing always proves to be advantageous to the practice of ecological rejuvenation.

\section{PRINCIPLE 3}

$>$ IS INFORMED BY NATIVE REFERENCE ECOSYSTEMS, WHILE CONSIDERING ENVIRONMENTAL CHANG

The potential of the indigenous species and communities to recuperate, redevelop, adjust and progress with the environmental changes are escalated by the reference models.

\section{PRINCIPLE 4}

\section{$>$ SUPPORTS ECOSYSTEM RECOVERY PROCESSES}

Specialists try to escalate or enrich the natural revival conducted by the plants and animals by interacting with each other and through their shared natural habitat and surroundings.

\section{PRINCIPLE 5}

$>$ IS ASSESSED AGAINST CLEAR GOALS AND OBJECTIVES USING MEASURABLE INDICATORS

In their preliminary phase, the vision, purposes of the restoration projects are certainly discovered, along with the identification of particular indicators useful for the measurement of their advancement.

\section{PRINCIPLE 6}

$>$ SEEKS THE HIGHEST LEVEL OF ECOSYSTEM RECOVERY POSSIBLE

Ecological restoration focuses on rate of feasible amelioration befitting all the conditions (Fig 8).

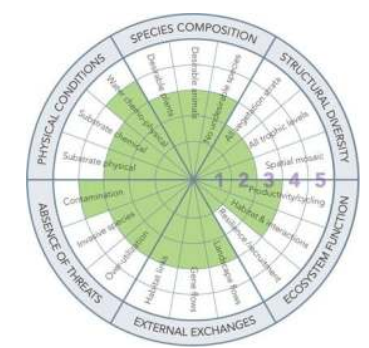

Baseline

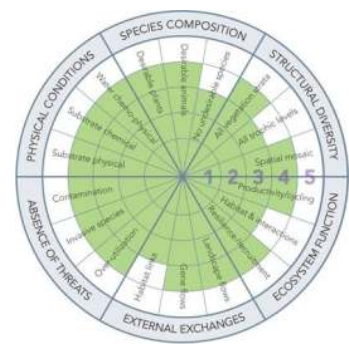

10 years later
Fig 8: Ecological Recovery Wheel (Gann and McDonald, 2019).

\section{PRINCIPLE 7}

$>$ GAIN CUMULATIVE VALUE WHEN APPLIED AT LARGE SCALES

Despite their spatial scale, ecosystem restoration projects show propitious end results efficiently. However, numerous restoration processes are exercised at a larger spatial scale such as the watershed or basin level. Also, to come to grips with the ecological sustainability requirements, the scaling-up of restoration actions is a desideratum.

\section{PRINCIPLE 8}

\section{$>$ IS PART OF A CONTINUUM OF} RESTORATIVE ACTIVITIES

Like many other schemes, ecological restoration is also one with great potentiality. To a significant extent, it can contribute to biodiversity 
preservation and management, hike up carbon sequestration and various benefits of a healthy ecosystem; bring about progression in human life that includes good health and livelihood; and also result in the enhancement of the relation between man and nature in a positive way (Fig 9).

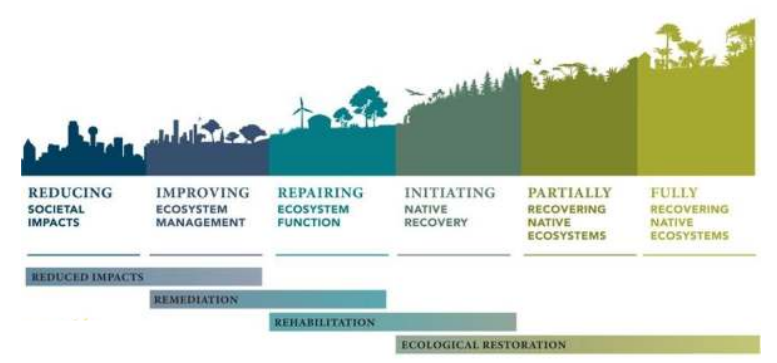

Fig 9. Restorative Continuum (Gann and McDonald, 2019).

\section{B. MAJOR CONDITIONS REQUIRED FOR ECOSYSTEM RESTORATION}

Highlighting the inter linkages between restoring ecosystem health and economic sustainability will be key to moving restoration forward in the context of the build-back better recovery plans, as well as to ensuring the equitable delivery of benefits (Aronson et al., 2020). Initiatives to raise awareness of the risks posed by ecosystem degradation will also be crucial for raising restoration finance.

Investing in ecosystem restoration will be fundamental to transitioning to sustainable economic development that works in balance with nature. Directing financial flows towards such investment requires better integration of information on ecosystems into economic planning tools. It also requires financial systems that channel investments towards economic activities that enhance, rather than degrade, ecosystems.

Despite the economic imperatives, over-exploitation of natural resources is embedded in our economies and governance systems. Breaking this habit requires recognizing the environmental externalities - the unaccounted-for consequences for nature and future generations - of our current approaches to planning economic development. Fundamental to this will be addressing perverse subsidies and other economic incentives that drive ecosystem degradation.

The path to a more sustainable use of ecosystems must begin with the development of inclusive wealth measures - which capture natural, social, human and manufactured capital and are thus more accurate ways to measure economic progress - and natural capital accounting.- The recent adoption of the System of Environmental Economic Accounting Ecosystem Accounting (SEEA EA) framework by the international statistical community is a major step towards the integration of ecosystems into national accounts and macroeconomic planning. It is a key part of the tool kit for reflecting the value of ecosystems in public policies, plans and economic systems.

Communities and civil society need to be engaged and supported to secure ecosystem restoration across scales. Public and private funds can help communities secure land tenure and support local investment in ecosystem restoration. Education is also vital to ensure that future generations benefit from a greater understanding of nature and an appreciation of its value.

\section{CONCLUSION}

Humans have been responsible for putting deep footprints on our natural environment bringing great destruction to our forests, ecosystems, wildlife and biodiversity. Several anthropogenic factors are responsible for this including habitat degradation and fragmentation, illegal human settlements in highly sensitive ecosystems and their dependence on local ecosystems for their daily sustenance, infringement into forests, anthropogenic wildfires, and changes in the land use patterns, conversion of forested areas into industrial sites and agricultural farmlands, infrastructure development projects to mention only a handful. The exponential rise in global human populations across the planet has been putting pressure on the local ecosystems beyond their individual threshold of their carrying capacity.

Hence, under the United Nations ecological restoration decade has been proposed and launched with an overall target of fulfilling 17 SDGs. In this major review work we have investigated the policies, strategies, success and failures of ecological restoration both across India as well as the world to get an unbiased local, regional and global perspective at various levels. Several successes and challenges have been identified and investigated. This has provided us with a grand opportunity to review and tackle the challenges associated with successful ecological restoration at the ground level. It is important to realize 
that this huge initiative is not just linked to environmental protection; but also with local and international economic developments. The COVID-19 pandemic has certainly slowed down the progress of ecological restoration due to several safety guidelines, protocols abs changed time line and schedule of work; but in spite of all odds some progress has been made. This is a mammoth task and several countries, government and non-government agencies, field experts and ordinary citizens participating in these initiatives need to understand the long term objectives of ecological restoration and need work together on a common platform to achieve deck success on the ground.

\section{REFERENCES}

1. 'Bio-restoration is helping revive degraded mangroves in Sunderbans'(2019); By Dinesh C Sharma;(https://www.downtoearth.org.in/news /wildlife-biodiversity/how-bio-restoration-ishelping revive-degraded-mangroves-insunderbans-66782).

2. Abraham, M. and Pingali, P. (2020). Transforming smallholder agriculture to achieve the SDGs. In The Role of Smallholder Farms in Food and Nutrition Security. Gomez y Paloma, S., Riesgo, L. and Louhichi, K. (eds.). Springer, Cham. 173- 209. https://doi.org/10.1007/978-3030-42148-9_9.

3. Alfthan, B., Agrawal, N. K., Andresen, M., Gjerdi, H. L., Jurek, M., Gupta, N. and Schoolmeester, T. (2018). Mountain Adaptation Outlook Series: Outlook on Climate Change Adaptation in the Hindu Kush Himalaya. Mountain Adaptation Outlook Series. UN Environment, GRID-Arendal, The International Centre for Integrated Mountain Development.

4. Aronson, J., Goodwin, N., Orlando, L., Eisenberg, C. and Cross, A.T. (2020). A world of possibilities: Six restoration strategies to support the United Nation's decade on ecosystem restoration. Restoration Ecology 28, 730-736. https:// doi.org/10.1111/rec.13170.

5. Babu, S., Love, A., and Babu, C. R. (2009). Ecological Restoration of Lantana-Invaded. Ecological Restoration, December, 467-477.

6. Barbut, M. and Alexander, S. (2016). Land Degradation as a Security threat amplifier: The new global frontline. In: Land Restoration: Reclaiming Landscapes for a Sustainable Future. Chabay, I., Frick, M. and Helgenson, J. (eds.) Academic Press. Chapter 1.1. Pages 3-12. https://doi.org/10.1016/B978- 0-12-8012314.00001- $X$.

7. Barrios-Ordoñez, J.E., Salinas-Rodríguez, S.A., López-Pérez, M., Villón- Bracamonte, R.A., Rosales-Ángeles, F., Guerra-Gilbert, A. and Sánchez- Navarro, R. (2015). National Water Reserves Program in Mexico. Experiences with Environmental Flows and the Allocation of Water for the Environment. InterAmerican Development Bank.

8. Bastin, J.F., Finegold, Y., Garcia, C., Mollicone, D., Rezende, M., Routh, D., et al. (2019). The global tree restoration potential. Science, 365(6448), 76-79. https://doi.org/ 10.1126/science.aax0848.

9. Beaumont, J.N., Aanesen, M., Austen, M.C., Börger, T., Clark, J.R., Cole, M., et al. (2019). Global ecological, social and economic impacts of marine plastic. Marine Pollution Bulletin 142, 189-195. https://doi.org/10.1016/j. marpolbul.2019.03.022.

10. Benton, T.G., Bieg, C., Harwatt, H., Pudasaini, R. and Wellesley, L. (2021). Food system impacts on biodiversity loss: Three levers for food system transformation in support of nature. Energy, Environment and Resources Programme. London: Chatham House.

11. Besseau, P., Graham, S. and Christophersen, T. (eds.). (2018). Restoring Forests and Landscapes: The Key to a Sustainable Future. Vienna: Global Partnership on Forest and Landscape Restoration. https://www. forestlandscaperestoration.org/ images/ gpflr_final\%2027aug.pdf.

12. Beyond conservation, why our natural ecosystems need restoration (2020); By Ramesh Venkataraman ; (https://www. downto earth.org.in/ blog/wildlife-biodiversity/beyondconservation-why-our-natural-ecosystemsneed-restoration-72564).

13. Binod, B., Bhattarcharjee, A., and Ishwar, N. M. (2018). Bonn Challenge and India: progress on restoration efforts across states and landscapes. Bonn Challenge and India: 
Progress on Restoration Efforts across States and Landscapes. https://doi.org/ 10.2305/ iucn.ch.2018.12.en.

14. Blue Forest (n.d.). Financial innovation for sustainable solutions. https://www. blueforest. org. Accessed 26 April 2021.

15. Bohissou, F. (2019). Technologies for land restoration showcased, 1 April. http://blog.wor ldagroforestry.org/index.php/2019/04/01/techn ologies-for-land-restoration-showcased/. Accessed 26 April 2021.

16. Bolch, T., Shea, J.M., Liu S., Azam, F.M., Gao, Y., Gruber, S., et al. (2019) Status and change of the cryosphere in the extended Hindu Kush Himalaya Region. In: The Hindu Kush Himalaya Assessment. Wester P., Mishra A., Mukherji A., Shrestha A. (eds). Springer, Cham. https://doi.org/10.1007/978-3-319-92288-1_7.

17. Bonn, A., Allott, T., Evans, M., Joosten, H. and Stoneman, R. (eds.) (2016). Peatland Restoration and Ecosystem Services: Science, Policy and Practice. Cambridge, United Kingdom: Cambridge University Press. https://doi. org/10.1017/ CBO978 1139177788.002.

18. Bossio, D. A., Cook-Patton, S. C., Ellis, P. W., Fargione, J., Sanderman, J., Smith, P., et al. (2020). The role of soil carbon in natural climate solutions. Nature Sustainability 3(5), 391-398. https://doi.org/10.1038/s41893-020-0491-z.

19. Bratman, G.N., Anderson, C.B., Berman, M.G., Cochran, B., de Vries, S., Flanders, J., et al. (2019). Nature and mental health: An ecosystem service perspective. Science Advances 5(7). https://doi.org/ 10.1126/ sciadv.aax0903.

20. Brauman, K.A., Siebert, S. and Foley, J.A. (2013). Improvements in crop water productivity increase water sustainability and food security: A global analysis. Environmental Research Letters 8(2). https://doi.org/ 10.1088/1748- 9326/8/2/024030.

21. Bullock, J. M., Aronson, J., Newton, A. C., Pywell, R. F. and Rey-Benayas, J. M. (2011). Restoration of ecosystem services and biodiversity: Conflicts and opportunities. Trends in Ecology and Evolution 26(10), 541549. https://doi.org/ https://doi.org/ 10.1016/j.tree. 2011.06.011z.
22. Burek, P., Satoh, Y., Fischer, G., Kahil, M.T., Scherzer, A., Tramberend, S., et al. (2016). Water Futures and Solution: Fast Track Initiative (Final Report). Laxenburg, Austria: IIASA.

23. Calderón, F. (2017). The Restoration Revolution, 17 April. https://www.wri.org/ insights/ restoration-revolution. Accessed 26 April 2021.

24. Carey, J. (2020). The best strategy for using trees to improve climate and ecosystems? Go natural. PNAS 117(9), 4434-4438. https://doi.org/10.1073/pnas.2000425117.

25. Castanẽda Camey, I., Sabater, L., Owren, C. and Boyer, A.E. (2020). Gender-based violence and environment linkages: The violence of inequality. Wen, J. (ed.). Gland, Switzerland: IUCN. https://doi.org/ 10.2305/ IUCN.CH.2020.03.en.

26. CBD (2014). An Updated Synthesis of the Impacts of Ocean Acidification on Marine Biodiversity. Hennige, S., Roberts, J.M. and Williamson, P. (eds.). Montreal, Canada: Secretariat of the Convention on Biological Diversity.

27. CBD (2018). South Africa: 6th National Report for the Convention on Biological Diversity. https://chm.cbd.int/pdf/documents/nationalRep ort6/241240/2.

28. CBD (2020a). Aichi Biodiversity Targets, September 2020. https://www.cbd. int/sp/targets/. Accessed 26 April 2021.

29. CBD (2020b). Global Biodiversity Outlook 5. Montreal, Canada: Secretariat of the Convention on Biological Diversity.

30. CBD (2021). Cities and Biodiversity Outlook. Montreal, Canada: Secretariat of the Convention on Biological Diversity.

31. Centre the Study of Science, Technology and Policy [CSTEP] (2020). Life Cycle Assessment of ZBNF and Non-ZBNF: A Preliminary Study in Andhra Pradesh, (CSTEP-RR-2020-02). https://cstep.in/drupal/sites/default/ files/202009/CSTEP_ZBNF_Report_Final_Latest.pdf.

32. Chamier, J., Schachtschneider, K., Le Maitre, D., Ashton, P. and van Wilgen, B. (2012). Impacts of invasive alien plants on water quality, with particular emphasis on South Africa. Water 
S.A 38, 345-356. https://doi.org/10.4314/ wsa.v38i2.19.

33. Chapman, T., Miles, S. and Trivedi, C. (2019). Capturing, protecting and restoring plant diversity in the UK: RBG Kew and the Millennium Seed Bank. Plant Diversity 41(2), 124-131. https:// doi.org/10.1016/ j.pld. 2018.06.001.

34. Cheng, L., Abraham, J., Hausfather, Z. and Trenberth, K.E. (2019). How fast are the oceans warming? Science 363(6423), 128-129. https://doi.org/10.1126/science.aav7619.

35. Collaborative Partnership on Forests [CPF] (2021). Challenges and Opportunities in Turning the Tide on Deforestation. Joint Statement of the Collaborative Partnership on Forests.

36. Conservation is Not Enough, We Need to Restore (2019) ; By Ramesh Venkataraman; (https://www.conservationindia.org/articles/co nservation-is-not-enough-we-need-to-restore).

37. Convention on Biodiversity [CBD] (2007). Mountain biodiversity: why is it important? 6 June. https://www.cbd.int/ mountain/ importance. shtml. Accessed 26 April 2021.

38. Cook-Patton, S.C., Gopalakrishna, T., Daigneault, A., Leavitt, S.M., Platt, J., Scull, S.M., Amarjargal, O., et al. (2020). Lower cost and more feasible options to restore forest cover in the contiguous United States for climate mitigation. One Earth 3(6), 739-753. https://doi.org/10.1016/j. oneear.2020.11.013.

39. Crump, J. (ed.) (2017). Smoke on Water: Countering Global Threats from Peatland Loss and Degradation. Nairobi and Arendal: United Nations Environment Programme and GRIDArendal.

40. Cunning, R., Silverstein, R.N., Barnes, B.B. and Baker, A.C. (2019). Extensive coral mortality and critical habitat loss following dredging and their association with remotelysensed sediment plumes. Marine Pollution Bulletin 145, 185-199. https://doi.org/ 10.1016/j.marpolbul.2019.05.02

41. Dainese, M., Martin, E.A., Aizen, M.A., Albrecht, M., Bartomeus, I., Bommarco, R., et al. (2019). A global synthesis reveals biodiversity-mediated benefits for crop production. Science Advances 5(10). https://doi.org/10.1126/sciadv.aax0121.

42. Darrah, S.E., Shennan-Farpón, Y., Loh, J., Davidson, N.C., Finlayson, C.M., Gardner, R.C. and Walpole, M.J. (2019). Improvements to the Wetland Extent Trends (WET) index as a tool for monitoring natural and human-made wetlands. Ecological Indicators 99, 294-298. https:// doi.org/ 10.1016/j. ecolind. 2018. 12.032 .

43. Das, S. and Vincent, J.R. (2009). Mangroves protected villages and reduced death toll during Indian super cyclone. PNAS 106(18) 73577360. https://doi. org/10.1073/ pnas.0810 440106.

44. Dasgupta, P. (2021). The Economics of Biodiversity: The Dasgupta Review. London: HM Treasury.

45. Davidson, N.C. (2014). How much wetland has the world lost? Long-term and recent trends in global wetland area. Marine and Freshwater Research 65, 934-941. http://dx.doi.org/ 10.1071/MF14173.

46. De Bievre, B., Calle, T., Velasco, P., Borja, P. and Nuñez, J. (2015). Restoration of Overgrazed Páramo Grasslands for Hydrological Benefits. Rome: FAO.

47. De Groot, R. S., Blignaut, J., van der Ploeg, S., Aronson, J., Elmqvist, T. and Farley, J. (2013). Benefits of investing in ecosystem restoration. Conservation Biology 27(6), 12861293. https://doi.org/10.1111/cobi.12158.

48. De Leeuw, J., Njenga, M., Wagner, B. and Iiyama, M., (eds.). (2014). Treesilience: An Assessment of the Resilience Provided by Trees in the Drylands Of Eastern Africa. Nairobi: World Agroforestry Center (ICRAF).

49. Deng, X. and Li, Z. (2016). Economics of land degradation in China. In Economics of Land Degradation and Improvement: A Global Assessment for Sustainable Development. Nkonya, E., Mirzabaev, A. and von Braun J. (eds). Springer, Cham. https://doi.org/10.1007/ 978-3-319-19168-3_13.

50. Dietzel, A., Bode, M., Connolly, S.R. and Hughes, T.P. (2020). Long-term shifts in the colony size structure of coral populations along the Great Barrier Reef. Proceedings of the Royal 
Society B 287: 20201432. https://doi. org/10.1098/rspb.2020.1432.

51. Ding, H., Faruqi, S., Wu, A., Altamirano, JC., Ortega, A.A., Zamora-Cristales, R., et al. (2018). Roots of Prosperity: The Economics and Finance of Restoring Land. Washington, DC: World Resources Institute.

52. Djenontin, I. and Djoudi, H. (2015). From degraded to functional restored forest land: Smallholder farmers curbing food insecurity in central Burkina Faso. In Enhancing Food Security Through Forest Landscape Restoration: Lessons from Burkina Faso, Brazil, Guatemala, Viet Nam, Ghana, Ethiopia and Philippines. Kumar, C., Begeladze, S., Calmon, M. and Saint-Laurent, C., (eds.). Gland: IUCN,18-41.

53. Dudley, N., Eufemia, L., Petersen, I., Fleckenstein, M., Campari, J., Periago, M.E., et al. (2020). Grassland and Savannah Ecosystems: An Urgent Need for Conservation and Sustainable Management. Berlin WWF.

54. Dzhambov, A.M., Lercher, P., Browning, M.H.E.M., Stoyanov, D., Petrova, N., et al. (2020). Does greenery experienced indoors and outdoors provide an escape and support mental health during the COVID-19 quarantine? Environmental Research, 110420. https://doi.org/ https://doi.org/ 10.1016/ j.envres. 2020.110420.

55. Earth Observatory (n.d.). The Aral Sea, Before the Streams Ran Dry. https://earthobservatory. nasa.gov/images/77193/the-aral-sea-beforethe-streams-ran-dry. Accessed 26 April 2021. ecological restoration.pdf. (n.d.).

56. Ecosystem restoration for people, nature and climate. (2021). In Ecosystem restoration for people, nature and climate. https://doi.org/ 10.4060/cb4927en.

57. Elmqvist, T., Setälä, H., Handel, S.N., van der Ploeg, S., Aronson, J., Blignaut, J.N., et al. (2015). Benefits of restoring ecosystem services in urban areas. Current Opinion in Environmental Sustainability 14, 101-108. https://doi.org/10.1016/j.cosust.2015.05.001.

58. European Environment Agency (2020). State of nature in the EU: Results from reporting under the nature directives 2013-18. Luxembourg: Publications Office of the European Union.

59. Evans, C.D., Williamson, J. M., Kacaribu, F., Irawan, D., Suardiwerianto, Y., Hidayat, et al. (2019). Rates and spatial variability of peat subsidence in Acacia plantation and forest landscapes in Sumatra, Indonesia. Geoderma 338, 410-421. https://doi.org/https:// doi.org/ 10.1016/j.geoderma.2018.12.028.

60. Everard, M., Johnston, P., Santillo, D. and Staddon, C. (2020). The role of ecosystems in mitigation and management of Covid-19 and other zoonoses. Environmental Science and Policy, 111, 7-17. https://doi.org/ 10.1016/ j.envsci.2020.05.017.

61. FAO (2016a). World Bank: Agricultural Land stats. https://data.worldbank.org/ indicator/ AG.LND.AGRI.K2. Accessed 26 April 2021.

62. FAO (2016b). The State of the World's Fisheries and Aquaculture: Contributing to Food Security and Nutrition for All. Rome: FAO.

63. FAO (2017). The Future of Food and Agriculture: Trends and Challenges. Rome: FAO.

64. FAO (2018). The State of the World's Forests 2018. Rome: FAO

65. FAO (2019). Forests: Nature-Based Solutions for Water. Unasylva 90. http://www.fao.org/3/ ca6842en/CA6842EN.pdf.

66. FAO (2020a). Peatland Mapping and Monitoring: Recommendations and Technical Overview. Rome: FAO. https:// doi.org/ 10.4060/ca8200en.

67. FAO (2020b). The State of World Fisheries and Aquaculture: Sustainability in Action. Rome: FAO.https://doi.org/10.4060/ca9229en.

68. FAO (2020c). Position paper on "Ecosystem Restoration" of production ecosystems, in the context of the UN Decade of Ecosystem Restoration 2021-2030. COFI/2020/Inf.15.2.

69. FAO (2021). Food and agriculture data. http://www.fao.org/faostat/en/\#home. Accessed 26 April 2021.

70. FAO and Intergovernmental Technical Panel on Soils [ITPS] (2015). Status of the World's Soil Resources: Main Report. Rome: FAO and ITPS. 
71. FAO and United Nations Convention to Combat Desertification [UNCCD] (2019). Vulnerability to Food Insecurity in Mountain Regions: Land Degradation and other Stressors. Bonn: UNCCD.

72. $\quad$ FAO and United Nations Environment Program (UNEP) (2020). The State of the World's Forests. Forests, Biodiversity and People. Rome: FAO. https://doi.org/10.4060/ca8642en.

73. Federal Democratic Republic of Ethiopia (2020). Launch of the 2020 green legacy treeplanting programme, 8 June. https://www.ethioembassy.org.uk/ primeminister-abiy-launches-2020-green-legacytree-planting-programme/. Accessed 26 April 2021.

74. Ferrario, F., Beck, M., Storlazzi, C., Micheli, F., Shepard, C.C. and Airoldi, L. (2014). The effectiveness of coral reefs for coastal hazard risk reduction and adaptation. Nature Communications 5(3794). https://doi.org/ 10.1038/ncomms4794.

75. Fodrie, F.J., Rodriguez, A.B., Gittman, R.K., Grabowski, J.H., Lindquist, N.L., Peterson, C.H., et al. (2017). Oyster reefs as carbon sources and sinks. Proceedings of the Royal Society B: Biological Sciences 284(1859). https://doi.org/10.1098/rspb.2017.0891.

76. Foley, J., Ramankutty, N., Brauman, K., Cassidy, E.S., Gerber, J.S., Johnston, M., et al. (2011). Solutions for a cultivated planet. Nature 478, 337-342. https://doi.org/ 10.1038/ nature10452.

77. Foley, J.A. (2011). Can we feed the world and Sustain the Planet? A five-step global plan could double food production by 2050 while greatly reducing environmental damage. Scientific American. https://www.scientific american.com/article/can-we-feed-the-wor ld/.

78. Food and Agriculture Organization of the United Nations [FAO] (2014). State of the Worlds Forests 2014: Enhancing the Socioeconomic Benefits from Forests. Rome: FAO.

79. Forest Peoples Programme [FPP] (2018). The Central Roles of Indigenous Peoples and Local Communities in Achieving Global Commitments on Biodiversity. Technical policy brief for the HPLF on Sustainable Development Goal 15.

80. Fraser, B. (2018). Around Itaipu Dam, restoring forests replenishes water invigorating livelihoods, 21 March. https://news.globall andscapesforum.org/26746/around-itaipu-damrestoring-forests-replenishes-water-invigorateslivelihoods/.Accessed 26 April 2021.

81. Friess, D.A., Rogers, K., Lovelock, C.E., Krauss, K.W., Hamilton, S.E., Lee, S.Y., et al. (2019). Annual Review of Environment and Resources 44(1) 89-115. https://doi.org/ 10.1146/annurev-environ-101718-033302.

82. Funge-Smith, S. and Bennet, A. (2019). A fresh look at inland fisheries and their role in food security and livelihoods. Fish and Fisheries 20(6), 1176-1195. https://doi.org/ 10.1111/faf.12403.

83. Gago, E.J., Roldan, J., Pacheco-Torres, R. and Ordóñez, J. (2013). The city and urban heat islands: A review of strategies to mitigate adverse effects. Renewable and Sustainable Energy Reviews 25, 749-758. https://doi.org/ 10.1016/j.rser.2013.05.057.

84. Galab, S., Prudhvikar Reddy, P., Sree Rama Raju, D., Ravi, C. and Rajani, A. (2019). Impact Assessment of Zero Budget Natural Farming in Andhra Pradesh - Kharif 2018-19: A Comprehensive Approach Using Crop Cutting Experiments. Telangana: Centre for Economic and Social Studies.

85. Gann, G. D., McDonald, T., Walder, B., Aronson, J., Nelson, C. R., Jonson, J., Hallett, J. G., Eisenberg, C., Guariguata, M. R., Liu, J., Hua, F., Echeverría, C., Gonzales, E., Shaw, N., Decleer, K., and Dixon, K. W. (2019). International principles and standards for the practice of ecological restoration. Second edition. Restoration Ecology, 27(S1), S1-S46. https://doi.org/10.1111/rec.13035.

86. Garnett, S.T., Burgess, N.D., Fa, J.E., Fernández-Llamazares, Á., Molnár, Z., Robinson, C.J., et al. (2018). A spatial overview of the global importance of Indigenous lands for conservation. Nature Sustainability 1(7), 369374. https://doi.org/10.1038/s41893-018-0100-6.

87. Gerla, P.J.; Cornett, M.W.; Ekstein, J.D.; Ahlering, M.A. (2012). Talking big: Lessons 
learned from a 9000-hectare restoration in the northern tallgrass prairie. Sustainability, 4(11), 3066-3087. https://doi.org/10.3390/su4113066.

88. Gibb, R., Redding, D.W., Chin, K.Q., Donnelly C.A., Blackburn, T.M., Newbold, T. and Jones, K.E. (2020). Zoonotic host diversity increases in human-dominated ecosystems. $\mathrm{N}$ a t u re $584, \quad 398-402$. https://doi.org/10.1038/s41586-020-2562-8.

89. Giller, K. E., Hijbeek, R., Andersson, J. A. and Sumberg, J. (2021). Regenerative agriculture: An agronomic perspective. Outlook on Agriculture 50(1), 13-25. https://doi.org/ 10.1177/0030727021998063.

90. Gilman, E.L. and Ellison, J. (2007). Efficacy of alternative low-cost approaches to mangrove restoration, American Samoa. Estuaries and Coasts 30(4), 641-651. https://doi.org/ 10.1007/BF02841961.

91. Global Environment Facility [GEF] (2020). The benefits of land restoration can accrue quickly, 30 June. Global Environment Facility. https://www.thegef.org/news/benefits-landrestoration-can-accrue-quickly. Accessed 26 April 2021.

92. Global Footprint Network (2021). Ecological Footprint. https://www.footprintnetwork.org/ our-work/ecological-footprint/. Accessed 26 April 2021.

93. Global Mangrove Alliance (n.d.). Mangrove Knowledge Hub. https://www.mangrove alliance.org/. Accessed 26 April 2021.

94. Global Tree Knowledge Platform (2021). Promoting the right tree in the right place for the right purpose. https://www.world agro forestry.org/ tree-knowledge. Accessed 26 April 2021.

95. Goswami, M., Chakraborty, P., Mukherjee, K., Dey, S., Mitra, G. and Tribedi, P. (2018). Bioaugmentation and biostimulation: A potential strategy for environmental remediation. Journal of Microbiology and Experimentation.6(5), 223-231. https://doi.org/ 10.15406/jmen.2018.06.00219.

96. Grantham, H.S., Duncan, A., Evans, T.D., Jones, K. R., Beyer, H. L., Schuster, R., et al. (2020). Anthropogenic modification of forests means only $40 \%$ of remaining forests have high ecosystem integrity. Nature Communications 11(5978). https://doi.org/10.1038/s41467-02019493-3.

97. Great Green Wall (2021). Growing a world wonder. https://www.greatgreenwall.org/aboutgreat-green-wall. Accessed 26 April 2021.

98. Griscom, B.W., Adams, J., Ellis, P.W., Houghton, R.A., Lomax, G., Miteva, D.A., et al. (2017). Natural climate solutions. Proceedings of the National Academy of Sciences 114(44), 11645-11650. https://doi.org/ 10.1073/pnas.1710465114.

99. Griscom, B.W., Lomax, G., Kroeger, T., Fargione, J.E., Adams, J., Almond, L., et al. (2019). We need both natural and energy solutions to stabilize our climate. Global Change Biology 25, 1889-1890. https://doi.org/ 10.1111/gcb.14612.

100.Haase, D.L. and David, A.S. (2017). Developing and supporting quality nursery facilities and staff are necessary to meet global forest and landscape restoration needs. REFORESTA0 4, $\begin{array}{lllll}6 & 9 & - & 9 & 3\end{array}$ https://doi.org/10.21750/REFOR.4.06.45.

101.Harris, N. L., Gibbs, D. A., Baccini, A., Birdsey, R. A., de Bruin, S., Farina, M., et al. (2021). Global maps of twenty-first century forest carbon fluxes. Nature Climate Change 11(3), 234-240. https://doi.org/10.1038/s41558-02000976-6.

102.High Level Panel of Experts on Food Security and Nutrition [HLPE] (2017). Sustainable Forestry for Food Security and Nutrition. A report by the High Level Panel of Experts on Food Security and Nutrition of the Committee on World Food Security. Rome: HPLE. http://www.fao.org/3/i7395e/i7395e.pdf.

103.HLPE (2019). Agroecological and other innovative approaches for sustainable agriculture and food systems that enhance food security and nutrition. A report by the High Level Panel of Experts on Food Security and Nutrition of the Committee on World Food Security. Rome: HPLE. https:// www.globalagriculture.org/ fileadmin/files/ weltagrarbericht/IAASTD-Buch/01Reports/ 11FAOAgroecology/HLPEAgroecologyReport. $p d f$. 
104. Hock, R., Rasul, G., Adler, C., Cáceres, B., Gruber, S., Hirabayashi, Y., Jackson, M., et al. (2019). High Mountain Areas. In IPCC Special Report on the Ocean and Cryosphere in a Changing Climate. Pörtner, H.O., Roberts, D.C., Masson-Delmotte, V., Zhai, P., Tignor, M., Poloczanska, E., Mintenbeck, K., Alegría, A., Nicolai, M., Okem, A., Petzold, J., Rama, B., Weyer, N.M. (eds.). Intergovernmental Panel on Climate Change [IPCC]. https://www.ipcc.ch/ site/ assets/uploads/sites/ 3/2019/12/ SROCC_FullReport_FINAL.pdf.

105. Hoekstra, A.Y. and Mekonnen M.M. (2012). The water footprint of humanity. PNAS 109(9), 3232-3237. https://doi.org/ 10.1073/ pnas. 1109936109.

106. Intergovernmental Panel on Climate Change [IPCC] (2014). Climate Change 2014: Mitigation of Climate Change. Contribution of Working Group III to the Fifth Assessment Report of the Intergovernmental Panel on Climate Change. Edenhofer, O., PichsMadruga, R., Sokona, Y., Farahani, E., Kadner, S., Seyboth, K., Adler, A., Baum, I., Brunner, S., Eickemeier, P., Kriemann, B., Savolainen, J., Schlömer, S., von Stechow, C., Zwickel, T. and Minx, J.C. (eds.). Cambridge and New York: Cambridge University Press.

107. Intergovernmental Science-Policy Platform on Biodiversity and Ecosystem Services [IPBES] (2018). The IPBES Assessment Report on Land Degradation and Restoration. Montanarella, L., Scholes, R. and Brainich, A. (eds.). Bonn: IPBES. https://doi.org/ 10.5281/zenodo.3237392.

108. International Labour Organization [ILO] (2016). Women at Work: Trends 2016. Geneva: ILO. https://www.ilo.org/gender/ Informationresources/Publications/ WCMS_457317/lang--en/index.htm.

109. International Resource Panel [IRP] (2019a). Land Restoration for Achieving the Sustainable Development Goals: An International Resource Panel Think Piece. Herrick, J.E., Abrahamse, T., Abhilash, P.C., Ali, S.H., Alvarez-Torres, P., Barau, A.S., Branquinho, C., Chhatre, A., Chotte, J.L., Cowie, A.L., Davis, K.F., Edrisi, S.A., Fennessy, M.S., Fletcher, S., Flores-Díaz,
A.C., Franco, I.B., Ganguli, A.C., Ifejika Speranza, C., Kamar, M.J., Kaudia, A.A., Kimiti, D.W., Luz, A.C., Matos, P., Metternicht, G., Neff, J., Nunes, A., Olaniyi, A.O., Pinho, P., Primmer, E., Quandt, A., Sarkar, P., Scherr, S.J., Singh, A., Sudoi, V., von Maltitz, G.P., Wertz, L. and Zeleke, G. (eds.) Nairobi: United Nations Environment Programme.

110. International Union for Conservation of Nature [IUCN] (2015). Conservation successes overshadowed by more species declines - IUCN Red List update, June 23. https://www.iucn.org/ content/conservation-successesovershadowed-more-species-declines-iucnred-list-update. Accessed 26 April 2021.

111. International Union of Forest Research Organizations [IUFRO] (2018). Global fire challenges in a warming world. Robinne F.-N., Burns J., Kant P., de Groot B., Flannigan M.D., Kleine M., Wotton D. M. (eds.). Occasional Paper No. 32. Vienna: IUFRO.

112. IPBES (2019). Summary for Policymakers of the Global Assessment Report on Biodiversity and Ecosystem Services of the Intergovernmental Science- Policy Platform on Biodiversity and Ecosystem Services. S. Díaz, J. Settele, E. S. Brondízio E.S., H. T. Ngo, M. Guèze, J. Agard, A. Arneth, P. Balvanera, K. A. Brauman, S. H. M. Butchart, K. M. A. Chan, L. A. Garibaldi, K. Ichii, J. Liu, S. M. Subramanian, G. F. Midgley, P. Miloslavich, Z. Molnár, D. Obura, A. Pfaff, S. Polasky, A. Purvis, J. Razzaque, B. Reyers, R. Roy Chowdhury, Y. J. Shin, I. J. Visseren-Hamakers, K. J. Willis and C. N. Zayas (eds.). Bonn: IPBES. https://doi.org/10.5281/zenodo.3553579.

113. IPBES. (2018). The IPBES assessment report on land degradation and restoration. Montanarella, L., Scholes, R., and Brainich, A. (eds.). Secretariat of the Intergovernmental Science-Policy Platform on Biodiversity and Ecosystem Services, Bonn, Germany. 744 pages.

114. IPCC (2018). Summary for Policymakers. In Global Warming of $1.5^{\circ} \mathrm{C}$. An IPCC Special Report on the Impacts of Global Warming of $1.5^{\circ} \mathrm{C}$ Above Pre- Industrial Levels and Related Global Greenhouse Gas Emission Pathways, in 
the Context of Strengthening the Global Response to the Threat of Climate Change, Sustainable Development, and Efforts to Eradicate Poverty. Masson-Delmotte, V., Zhai, P., Pörtner, H.-O., Roberts, D., Skea, J., Shukla, P.R., Pirani, A., Moufouma-Okia, W., Péan, C., Pidcock, R.,Connors, S., Matthews, J.B.R., Chen, Y., Zhou, X., Gomis, M.I., Lonnoy, E., Maycock, T., Tignor, M. and Waterfield, T. (eds.). Geneva: World Meteorological Organization.

112. IPCC (2019). Summary for Policymakers. In: IPCC Special Report on the Ocean and Cryosphere in a Changing Climate. Pörtner, H.O., Roberts, D.C., Masson- Delmotte, V., Zhai, P., Tignor, M., Poloczanska, E., Mintenbeck, K., Alegría, A., Nicolai, M., Okem, A., Petzold, J., Rama, B. and Weyer, N.M. (eds.). IPCC.

113. IRP (2019b). Restore landscapes to push ahead on sustainable development, says International Resource Panel. 5 S eptember. https://www.unep.org/ news-and-stories/pressrelease/restore-landscapes-push-aheadsustainable-development-says.

114. IUCN (2017). Gender-responsive restoration guidelines: A closer look at gender in the Restoration Opportunities Assessment Me thod o log y. G l a nd: I U C N . https://portals.iucn.org/library/node/46693.

115. IUCN (2020). IUCN Global Ecosystem Typology 2.0: descriptive profiles for biomes and ecosystem functional groups. Gland: IUCN. https://doi. org/10.2305/IUCN.CH.2020.13.en.

116. IUCN CEM (n.d.). Rewilding Principles. https://www.iucn.org/commissions/ commission-ecosystem-management/ourwork/cems-thematic-groups/ rewilding. Accessed 26 April 2021.

117. Jang, W. S., Neff, J. C., Im, Y., Doro, L. and Herrick, J. E. (2020). The hidden costs of land degradation in US maize agriculture. Earth's Future 9(2). https:// doi.org/10.1029/ 2020 EF001641.

118. Johnson, J.A., Baldos, U., Hertel, T., Liu, J., Nootenboom, C., Polasky, S. and Roxburgh, T. (2020). Global Futures: Modelling the Global Economic Impacts of Environmental Change to
Support Policy-Making. WWF UK. https://www. wwf.org.uk/globalfutures.

119. Jones, H. P. (2013). Impact of Ecological Restoration on Ecosystem Services. In Encyclopedia of Biodiversity: Second Edition (Vol. 4). Elsevier Ltd. https://doi.org/ 10.1016/B978-0-12-384719-5.00326-9.

120. Jones, H. P., Jones, P. C., Barbier, E. B., Blackburn, R. C., Rey Benayas, J. M., Holl, K. D., McCrackin, M., Meli, P., Montoya, D., and Mateos, D. M. (2018). Restoration and repair of Earth's damaged ecosystems. Proceedings of the Royal Society B: Biological Sciences, 285(1873). https://doi.org/ 10.1098/ rspb.2017.2577

121. Joosten, H. (2009). The Global Peatland CO2 Picture: Peatland Status and Drainage Related Emissions in all Countries of the World. Ede: Wetlands International. https://www. wetlands.org/ publications/the-globalpeatland-co2-picture/.

122. Jose, S. (2009). Agroforestry for ecosystem services and environmental benefits: An overview. Agroforestry Systems 76, 1-10. https://doi.org/10.1007/s10457-009-9229-7.

123. Kapos, V., Wicander, S., Salvaterra, T., Dawkins, K. and Hicks, C. (2019). The Role of the Natural Environment in Adaptation: Background Paper for the Global Commission on Adaptation. Rotterdam and Washington, D.C.: Global Commission on Adaptation.

124. Keeble, N. H. (2015). The Restoration Initiative (Issue November 2015). http://www.forestlands caperestoration.org/sites/default/files/resource/ 2015-11-24_tri_flyer_print_final.pdf

125. Kirpotin, S. N., Antoshkina, O. A., Berezin, A. E., Elshehawi, S., Feurdean, A., Lapshina, E. D., et al. (2021). Great Vasyugan Mire: How the world's largest peatland helps addressing the world's largest problems. Ambio. https://doi. org/10.1007/s13280-021-01520-2.

126. Konar, M. and Ding, H. (2020). A Sustainable Ocean Economy for 2050: Approximating Its Benefits and Costs. High Level Panel for a Sustainable Ocean Economy. https:// www.oceanpanel.org/economicanalysis.

127. Kopittke, P. M., Menzies, N. W., Wang, P., McKenna, B. A. and Lombi, E. (2019). Soil 
and the intensification of agriculture for global food security. Environment International 132. https://doi.org/https://doi.org/10.1016/j. envint.2019.105078.

128. Kroeger, T. (2012). Dollars and sense: Economic benefits and impacts from two oyster reef restoration projects in the Northern Gulf of Mexico. The Nature Conservancy. https://www. conservationgateway.org/Documents/2_Oyster $\% 20$ restoration\% 20 study_Kroeger\% 20May\% 209\%202012.pdf. Accessed 20 May 2021.

129. Kroll, C., Warchold, A., and Pradhan, P. (2019). Sustainable Development Goals (SDGs): Are we successful in turning trade-offs into synergies? Palgrave Communications, 5(1), 1-11. https://doi.org/10.1057/s41599-0190335-5.

130. Land Restoration for Achieving the Sustainable Development Goals. (2020). In Land Restoration for Achieving the Sustainable Development Goals. https://doi.org/ 10.18356/799094c6-en.

131. Landrigan, P.J., Fuller, R., Acosta, N.J.R., Adeyi, O., Arnold, N.N., Baldé, A.B. et al. (2017). The Lancet Commission on pollution and health. The Lancet 391(10119), 1-57. https://doi.org/10.1016/S0140-6736(17)323450 .

132. Leclère, D., Obersteiner, M., Barrett, M., Butchart, S. H. M., Chaudhary, A., De Palma, A., et al. (2020). Bending the curve of terrestrial biodiversity needs an integrated strategy. Nature 585(7826), 551-556. https://doi.org/10.1038/ s41586-020-2705-y.

133. Lehner, B. and Döll, P. (2004). Development and validation of a global database of lakes, reservoirs and wetlands. Journal of Hydrology 296, 1-22. http://dx.doi.org/ 10.1016/j.jhydrol. 2004.03.028.

134. Leifeld, J. and Menichetti, L. (2018). The underappreciated potential of peatlands in global climate change mitigation strategies. Nature Communications 9, 1071. https://doi.org/10.1038/s41467-018-03406-6.

135. Leifeld, J., Wüst-Galley, C. and Page, S. (2019). Intact and managed peatland soils as a source and sink of GHGs from 1850 to 2100. Nature Climate Change 9(12), 945-947. https://doi.org/10.1038/s41558-019-0615-5.

136. Li, X., Manman, C. and Anderson, B. C. (2009). Design and performance of a water quality treatment wetland in a public park in Shanghai, China. Ecological Engineering 35(1), 18-24. https://doi.org/https://doi.org/10.1016/j. ecoleng.2008.07.007.

137. Lim, H.S. and Lu, X.X. (2016). Sustainable urban stormwater management in the tropics: An evaluation of Singapore's ABC Waters Program. Journal of Hydrology 538, 842-862. https://doi.org/10.1016/j.jhydrol.2016.04.063.

138. Loodin, N. (2020). Aral Sea: an environmental disaster in twentieth century in Central Asia. Modeling Earth Systems and Environment 6, 2495-2503. https:// doi.org/10.1007/s40808020-00837-3.

139. López Gonzales, M., Hergoualc'h, K., Núñez, A., Baker, T., Chimner, R., Del AguilaPasquel, J., et al. (2020). What Do We Know About Peruvian Peatlands? Occasional Paper 210. Bogor, Indonesia: Center for International Forestry Research (CIFOR). https://doi.org/ 10.17528/cifor/007848.

140. Losada, I.J., Menéndez, P., Espejo, A., Torres, S., Díaz-Simal, P., Abad, S., et al. (2018). The Global Value of Mangroves for Risk Reduction. Berlin, Germany: The Nature Conservancy. https://doi.org/10.7291/V9DV1H2S.

141. MacDonald, R., Kroeger, T., Boucher, T., Longzhu, W. and Salem, R. (2016). Planting Healthy Air: A Global Analysis of the Role Of Urban Trees in Addressing Particulate Matter Pollution and Extreme Heat. Arlington, VA: The Nature Conservancy.

142. Managi, S. and Kumar, P. (2018). Inclusive Wealth Report 2018: Measuring Progress Towards Sustainability. London: Routledge. https://doi. org/10.4324/9781351002080.

143. Mansourian, S. (2020). Enabling Factors to Scale Up Forest Landscape Restoration: The Roles of Governance and Economics: Full Report with Case Studies. Germany: WWF.

144. Mansourian, S., Diederichsen, A. and Vallauri, D. (forthcoming) Experiences in Forest Landscape Restoration. WWF-France. 
145. Mansuy, N. ( ( 2 02020$)$. S timulating post-COVID-19 green recovery by investing in ecological restoration. Restoration Ecology 28, 1343-1347. https://doi.org/10.1111/rec.13296.

146. Marlier, M. E., Liu, T., Yu, K., Buonocore, J. J., Koplitz, S. N., DeFries, R. S., et al. (2019). Fires, smoke exposure, and public health: An integrative framework to maximize health benefits from peatland restoration. GeoHealth 3(7), 178-189. https://doi.org/https:// doi.org/10.1029/2019GH000191.

147. Mbaabu, P. R., Olago, D., Gichaba, M., Eckert, S., Eschen, R., Oriaso, S., et al. (2020). Restoration of degraded grasslands, but not invasion by Prosopis juliflora, avoids trade-offs between climate change mitigation and other ecosystem services. Scientific Reports 10(1). https://doi.org/10.1038/s41598-020-77126-7.

148. Mbow, C., Rosenzweig, C., Barioni, L.G., Benton, T.G., Herrero, M., Krishnapillai, M., et al. (2019). Food Security. In Climate Change and Land: An IPCC Special Report on Climate Change, Desertification, Land Degradation, Sustainable Land Management, Food Security, and Greenhouse Gas Fluxes in Terrestrial Ecosystems. Shukla, P.R., Skea, J., Calvo Buendia, E., Masson-Delmotte, V., Pörtner, H.O., Roberts, D.C., Zhai, P., Slade, R., Connors, S., van Diemen, R., Ferrat, M., Haughey, E., Luz, S., Neogi, S., Pathak, M., Petzold, J., Portugal Pereira, J., Vyas, P., Huntley, E., Kissick, K., Belkacemi, M. and Malley, J. (eds.). IPCC.

149. Mcdonald, R., Colbert, M., Hamann, M., Simkin, R., Walsh, B., Ascensão, F. et al. (2018). Nature in the Urban City: A Global Assessment of Where and how to Conserve Nature for Biodiversity and Human Wellbeing. Arlington, VA: The Nature Conservancy.

150. McDonald, R.I. and Shemie, D. (2014). Urban Water Blueprint: Mapping Conservation Solutions To The Global Water Challenge. Washington, D.C.: The Nature Conservancy.

151. Mekonnen, M.M. and Hoekstra, A.Y. (2016). Four billion people facing severe water scarcity. Science Advances 2(2). https://doi.org/ 10.1126/sciadv.1500323.
152. Mirova (2019). Mobilising Private Capital for Land and Ecosystem Restoration. Luxembourg: Global Landscapes Forum.

153. Mishra, U. (2019). India Science Wire. May, 4-7.

154. Monga, P. (2018). Landscapes of peace: using land restoration for conflict resolution. Keynote speech to the United Nations Convention to Combat Desertification. Caux, Switzerland, 17 July. https: //www.unccd.int/ sites/default/files/inline-files/CAUX\%20 Forum\% 20Final\%20 Speech.pdf.

155. Mor, M.T. (2018). Towards a gender-responsive implementation of the United Nations Convention to Combat Desertification. New York: UN Women. https://www.unwomen.org/ en/digital-library/publications/2018/2/ towards-a-gender-responsive-implementationof - the - un - convention-to-combatdesertification.

156. Morand, S. and Lajaunie, C. (2021). Outbreaks of vector-borne and zoonotic diseases are associated with changes in forest cover and oil palm expansion at global scale. Frontiers in Veterinary Science 8, 230. https://doi.org/ 10.3389/fvets.2021.661063.

157. Mortimore, M. with contributions from Anderson, S., Cotula, L., Davies, J., Faccer, K., Hesse, C., Morton, J., et al. (2009). Dryland Opportunities: A New Paradigm for People, Ecosystems and Development. Gland: IUCN; London, UK: IEED; and Nairobi: UNDP/DDC.

158. Mountford, H., et al. (2018). Unlocking the inclusive growth story of the 21st Century: Accelerating climate action in urgent times. Washington, D.C.: WRI. https://doi.org/ 10.13140/RG.2.2.23326.28488.

159. Muchane, M. N., Sileshi, G. W., Gripenberg, S., Jonsson, M., Pumariño, L. and Barrios, E. (2020). Agroforestry boosts soil health in the humid and sub-humid tropics: A meta-analysis. Agriculture, Ecosystems and Environment 295. https://doi.org/10.1016/j.agee.2020.106899.

160 Mulinge, W., Gicheru, P., Murithi, F., Maingi, P., Kihiu, E., Kirui, O. K. and Mirzabaev, A. (2015). Economics of land degradation and improvement in Kenya. In Economics of Land 
Degradation and Improvement - A Global Assessment for Sustainable Development. Nkonya, E., Mirzabaev, A. and von Braun, J. (eds.). 471-498. Springer International Publishing. https://doi.org/10.1007/978-3-31919168-3_16.

161. National Oceanic and Atmospheric Administration [NOAA] (2020a). How much of the ocean have we explored? https://oceanservice.noaa.gov/facts/exploratio n.html. Accessed 26 April 2021.

162. NOAA (2020b). How much oxygen comes from the ocean? https://oceanservice.noaa.gov/ facts/ocean-oxygen.html. Accessed 26 April 2021.

163. Noel, S., Mikulcak, F., Etter, H. and Stewart, N. (2015). Economics of Land Degradation Initiative: Report for Policy and Decision Makers. Bonn: ELD Initiative and Deutsche Gesellschaft für Internationale Zusammenarbeit (GIZ) GmbH.

164. O'Callaghan, B.J. and Murdock, E. (2021). Are We Building Back Better? Evidence from 2020 and Pathways to Inclusive Green Recovery Spending. Nairobi: UNEP. https:// www.unep.org/resources/publication/are-webuilding-back-better-evidence-2020-andpathways-inclusive-green.

165. O'Mahoney, J., Simes, R., Redhill, D., Heaton, K., Atkinson, C., Hayward, E. and Nguyen, M. (2017). At What Price? The Economic, Social and Icon Value Of The Great Barrier Reef. Deloitte Access Economics.

166. O'Mara, F.P.O. (2012). The role of grasslands in food security and climate change. Annals of Botany 110(6), 1263-1270. https:// doi.org/10.1093/aob/mcs209.

167. OECD (2021). Costa Rica: OECD Tourism Trends and Policies 2020. https://www.oecdilibrary.org/sites/37bb0cf5-en/index.html? itemId $=/$ content/ component/ 37bb0cf5-en. Accessed 26 April 2021.

168. Office of the United Nations High Commissioner for Human Rights [OHCHR] (2018). Framework Principles on Human Rights and the Environment. A/HRC/37/59. Geneva: OHCHR. https://undocs.org/A/HRC/37/59.
169. Olivero, J., Fa, J. E., Real, R., Farfán, M. Á., Márquez, A. L., Vargas, J. M., (2017). Mammalian biogeography and the Ebola virus in Africa. Mammal Review 47(1), 24-37. https://doi.org/https://doi.org/10.1111/mam.12 074.

170. Olivier, J.G.J. and Peters, J.A.H.W. (2019) Trends in global CO2 and total greenhouse gas emissions 2019. The Hague: PBL Netherlands Environmental Assessment Agency. https://www.pbl.nl/sites/default/files/download s/pbl-2020-trends-in-global-co2-and-totalgreenhouse-gas-emissions-2019report_4068.pdf.

171. Olsson, L., Barbosa, H., Bhadwal, S., Cowie, A., Delusca, K., Flores-Renteria, D., et al. (2019). Land degradation. In Climate Change and Land: An IPCC Special Report on Climate Change, Desertification, Land Degradation, Sustainable Land Management, Food Security, and Greenhouse Gas Fluxes in Terrestrial Ecosystems. Shukla, P.R., Skea, J., Calvo Buendia, E., Masson-Delmotte, V., Pörtner, H.O., Roberts, D. C., Zhai, P., Slade, R., Connors, S., van Diemen, R., Ferrat, M., Haughey, E., Luz, S., Neogi, S., Pathak, M., Petzold, J., Portugal Pereira, J., Vyas, P., Huntley, E., Kissick, K., Belkacemi, M. and Malley, J. (eds.) IPCC.

172. Organisation for Economic Co-operation and Development [OECD] (2020). Biodiversity and the economic response to COVID-19: Ensuring a green and resilient recovery. In OECD Policy Responses to Coronavirus (COVID-19). OECD. https://www.oecd.org/coronavirus/policyresponses/biodiversity-and-the-economicresponse-to-covid-19-ensuring-a-green-andresilient-recovery-d98b5a09/.

173. Osuri, A. M., Kasinathan, S., Siddhartha, M. K., Mudappa, D., and Raman, T. R. S. (2019). Effects of restoration on tree communities and carbon storage in rainforest fragments of the Western Ghats, India. Ecosphere, 10(9). https://doi.org/10.1002/ecs2.2860.

174. Palomares, M. L. D., Froese, R., Derrick, B., Meeuwig, J. J., Nöel, S.-L., Tsui, G., Woroniak, J., Zeller, D. and Pauly, D. (2020). Fishery biomass trends of exploited fish 
populations in marine ecoregions, climatic zones and ocean basins. Estuarine, Coastal and Shelf Science 243, 106896. https:// doi.org /https:// doi.org/10.1016/j.ecss.2020.106896.

175. Panagos, P., Standardi, G., Borrelli, P., Lugato, E., Montanarella, L. and Bosello, F. (2018). Cost of agricultural productivity loss due to soil erosion in the European Union: From direct cost evaluation approaches to the use of macroeconomic models. Land Degradation and Development 29(3), 471-484. https://doi.org/ https://doi.org/10.1002/ldr.2879.

176. Pattnaik, A. K. and Kumar, R. (2018). Lake Chilika (India): Ecological restoration and adaptive management for conservation and wise use BT. In The Wetland Book II: Distribution, Description, and Conservation. C. M. Finlayson, G. R. Milton, R. C. Prentice, and N. C. Davidson (eds.). N et herlands: S pringer. https://doi.org/10.1007/978-94-007-40013_177.

177. Perefán, C. and Pabón, M. (2019). Comunidades sostenibles: Evaluación socio cultural del Programa Socio Bosque. Banco Interamericano de Desarrollo. http:// dx.doi.org/10.18235/0001643.

178. Perring, M. P., Erickson, T. E. and Brancalion, P. H. S. (2018). Rocketing restoration: enabling the upscaling of ecological restoration in the Anthropocene. Restoration Ecology 26(6), 1017-1023. https://doi.org/ https://doi.org/10.1111/rec.12871.

179. Pharo, P., Oppenheim, J., Pinfield, M., Laderchi, C.R., Benson, S., Polman, P., (2019). Growing Better: Ten Critical Transitions to Transform Food and Land Use. The Food and L and Use Coalition. https:// www.foodandlandusecoalition.org/globalreport/.

180. Prăvălie, R. (2016). Drylands extent and environmental issues. A global approach. EarthScience Reviews 161, 259-278. https://doi.org/ 10.1016/j.earscirev.2016.08.003.

181. Prăvălie, R., Patriche, C., Borrelli, P., Panagos, P., Roșca, B., Dumitraşcu, M., et al. (2021). Arable lands under the pressure of multiple land degradation processes. A global perspective. Environmental Research 194, 110697 . https:// doi.org/https:// doi.org/10.1016/j.envres.2020.110697.

182. Ramsar (2018). Scaling Up Wetland Conservation, Wise Use and Restoration to Achieve the Sustainable Development Goals. https://www.ramsar.org/document/wetlandsand-the-sdgs.

183. Regreening Africa App (n.d.). User Guidelines. ht tps://regreeningafrica.org/wpcontent/uploads/2020/01/Regreening_Africa_A pp_User_Guide_English-1.pdf.

184. Reguero, B.G., Beck, M.W., Bresch, D.N., Calil, J. and Meliane, I. (2018). Comparing the cost effectiveness of nature-based and coastal adaptation: A case study from the Gulf Coast of the United States. PLOS ONE. https://doi.org/ 10.1371/journal.pone.0192132.

185. Reid, A. J., Carlson, A. K., Hanna, D. E. L., Olden, J. D., Ormerod, S. J. and Cooke, S. J. (2020). Conservation Challenges to Freshwater Ecosystems. In Encyclopedia of the World's Biomes. 270-278. https://doi.org/ 10.1016/B978-0-12-409548-9.11937-2.

186. Restoration Factory (2021). Co-create restoration projects that change the world. https://programs.bridgeforbillions.org/restorat ion-factory-program/. Accessed 4 May 2021.

187. Reytar, K., Martin, O., Landsberg, F., Ray, S., Gallo Granizo, C., Zamora Cristales, R., et al. (2021). Mapping together: A guide to monitoring forest and landscape restoration using Collect Earth Mapathons. Rome, Washington, DC: FAO and WRI. https://doi.org/10.4060/cb2714en.

188. Robertson, H.G. (2020). Summary of Initiatives In The Covid-19 Response And Recovery Fund (Crrf) Foundational Package. New Zealand Government. treasury.govt.nz/ publications/summary-intiatives/summaryinitiatives-crrf-budget2020.

189. Romeo, R., Grita, F., Parisi, F. and Russo, L. (2020). Vulnerability of Mountain Peoples to Food Insecurity: Updated Data and Analysis of Drivers. Rome: FAO and UNCCD. https://doi.org/10.4060/cb2409en.

190. Ruzicka, K. J. (2017). Ecological restoration of southwestern ponderosa pine ecosystems: A 
broad perspective. The Journal of Ecology, 105(5), 1418-1433. https://doi.org/ 10.7267/N9QJ7F7B.

191. Rycerz, R., Bugler W., Messling, L. and Wade, G. (2020). Itaipú Dam: How natural ecosystems support one of the world's largest hydroelectric $\mathrm{dams}$. The Resilience Shift . https://www.resilienceshift.org/wp-content/ uploads/2020/08/Itaipu-Dam-case-studyResilience-Shift.pdf.

192. Safriel, U., Adeel, Z., Niemeijer, D., Puigdefabregas, J., White, R., Lal, R., et al. (2005). The Millennium Assessment: Dryland systems. In Ecosystems and Human Well-being: Current State and Trends. Washington, D.C.: Island Press.

193. Scharlemann, J. P. W., Tanner, E. V. J., Hiederer, R. and Kapos, V. (2014). Global soil carbon: understanding and managing the largest terrestrial carbon pool. Carbon Management 5(1), 81-91. https://doi.org/10.4155/cmt.13.77.

194. Schmidtko, S., Stramma, L. and Visbeck, M. (2017). Decline in global oceanic oxygen content during the past five decades. Nature 542(7641), 335-339.

195. Schreefel, L., Schulte, R. P. O., de Boer, I. J. M., Schrijver, A. P. and van Zanten, H. H. E. (2020). Regenerative agriculture: The soil is the base. Global Food Security 26, 100404. https://doi.org/https://doi.org/10.1016/j. gfs.2020.100404.

196. Searchinger, T., White, R., Hanson, C. and Ranganathan, J. (2019). Creating a Sustainable Food Future: A Menu of Solutions to Feed Nearly 10 Billion People by 2050. Washington, D.C.: WRI.

197. SER (n.d.). Restoration Resource Center. Society for Ecological Restoration https://www.ser-rrc.org/. Accessed 26 April 2021.

198. SERISPWG. (2004). The Society for Ecological Restoration International Primer on Ecological Restoration. Ecological Restoration, 2(2), 206-207.

199. Sewell, A., van der Esch, E. and Löwenhardt, H. (2020). Goals and Commitments for the Restoration Decade: A Global Overview of
Countries' Restoration Commitments Under the Rio Conventions and other Pledges. The Hague: PBL Netherlands Environmental Assessment A g e n c y. ht t ps: // www.pbl. nl/sites/default/files/downloads/pbl-2020goals-and-commitments-for-the-restorationdecade-3906.pdf.

200. Shepard, C.C., Crain, C.M. and Beck, M.W. (2011). The protective role of coastal marshes: A systematic review and meta-analysis. PLOS ONE. https:// doi.org/ 10.1371/ journal.pone.0027374.

201. Sijapati Basnett, B.; Elias, M.; Ihalainen, M.; Paez Valencia, A.M. (2017). Gender matters in Forest Landscape Restoration: A framework for design and evaluation. Bogor, Indonesia: Center for International Forestry Research (CIFOR). https://www.cifor.org/knowledge/publication/6 685.

202. Singh, R., Shelar, K., Chaturvedi, R., Duraisami, M., and Singh Gautam, R. (2020). Restoring Landscapes in India for Climate and Communities. World Resources Institute, 3-6. https://doi.org/10.46830/wrirpt.18.00005.

203. Smith, P., Nkem, J., Calvin, K., Campbell, D., Cherubini, F., Grassi, G., et al. (2019). Interlinkages between desertification, land degradation, food security and greenhouse gas fluxes: Synergies, trade-offs and integrated response options. In Climate Change And Land: An IPCC Special Report on Climate Change, Desertification, Land Degradation, Sustainable Land Management, Food Security, and Greenhouse Gas Fluxes in Terrestrial Ecosystems. Shukla, P.R., Skea, J., Calvo Buendia, E., Masson-Delmotte, V., Portner, H.O., Roberts, D. C., Zhai, P., Slade, R., Connors, S., van Diemen, R., Ferrat, M., Haughey, E., Luz, S., Neogi, S., Pathak, M., Petzold, J., Portugal Pereira, J., Vyas, P., Huntley, E., Kissick, K., Belkacemi, M. and Malley, J. (eds.). IPCC.

204. Snoussi, M., Kitheka, J., Shaghude, Y., Kane, A., Arthurton, R., Le Tissier, M. and Virji, H., (2007). Downstream and coastal impacts of damming and water abstraction in Africa. Environmental Management 39(5), 587-600. https://doi. org/10.1007/s00267-004-0369-2. 
205. Solomon, G.M., Morello-Frosch, R., Zeise, L. and Faust, J.B. (2016). Cumulative environmental impacts: Science and policy to protect communities. Annual Review of Public Health 37, 83-96. https://doi.org/ 10.1146/ annurev-publhealth-032315-021807.

206. Soorae, P.S. (2021). Global conservation translocation perspectives: 2021. Case Studies from Around the World. Calgary: IUCN SSC Conservation Translocation Specialist Group, Environment Agency. https://portals.iucn.org/ library/sites/library/files/documents/2021-007En.pdf.

207. Spalding, M., McIvor, A., Tonneijck, F.H., Tol, S. and van Eijk, P. (2014). Mangroves for coastal defence: Guidelines for coastal managers and policy makers. Wetlands International and The Nature Conservancy.

208. Spencer, T., Schuerch, M., Nicholls, R. J., Hinkel, J., Lincke, D., Vafeidis, A. T., et al. (2016). Global coastal wetland change under sea-level rise and related stresses: The DIVA Wetland Change Model. Global and Planetary Change 139, 15-30. https://doi.org/ https://doi.org/10.1016/j.gloplacha.2015.12.01 8.

209. Stoeckl, N., Jackson, S., Pantus, F., Finn, M., Kennard, M. J. and Pusey, B. J. (2013). An integrated assessment of financial, hydrological, ecological and social impacts of 'development' on Indigenous and non-Indigenous people in northern Australia. Biological Conservation 159, 214-221. https://doi.org/ https://doi.org/ 10.1016/j.biocon.2012.12.007.

210. Stramma, L., Schmidtko, S., Levin, L.A. and Johnson, G.C. (2010). Ocean oxygen minima expansions and their biological impacts. Deep Sea Research Part I: Oceanographic Research Papers, 57(4), pp.587-595.

211. Strassburg, B. B. N., Beyer, H. L., Crouzeilles, R., Iribarrem, A., Barros, F., de Siqueira, M. F., et al. (2019). Strategic approaches to restoring ecosystems can triple conservation gains and halve costs. Nature Ecology and Evolution 3(1), 62-70. https://doi.org/ 10.1038/s41559-018-0743-8.

212. Strassburg, B. B. N., Iribarrem, A., Beyer, H. L., Cordeiro, C. L., Crouzeilles, R., Jakovac,
C. C., et al. (2020). Global priority areas for ecosystem restoration. Nature 586(7831), 724729. https://doi.org/10.1038/s41586-020-27849.

213. Suazo, A.E. (2015). Climate change, ecological restoration and conflict resolution, 6 February. https://www.peaceinsight.org/en/articles/clima te-change-ecological-restoration-conflictresolution/?location $=$ andtheme $=$ environm ent. Accessed 26April 2021.

214. Tanneberger, F., Appulo, L., Ewert, S., Lakner, S., Ó Brolcháin, N., Peters, J. and Wichtmann, W. (2021). The power of naturebased solutions: How peatlands can help us to achieve key EU sustainability objectives. Advanced Sustainable Systems, 5(1), 2000146. https://doi.org/10.1002/adsu.202000146.

215. Tanneberger, F., Tegetmeyer, C., Busse, S., Barthelmes, A., Shumka, S., Moles Mariné, A., et al. (2017). The peatland map of Europe. Mires and Peat 19 (22), 1-17. https://doi.org/10.19189/MaP.2016.OMB.264.

216. Taylor, L., S. Latham and M. Woolhouse (2001). Risk factors for human disease emergence. Philosophical Transactions of the Royal Society of London. Series B: Biological Sciences, 356 (1411), 983-989. https://doi. org/10.1098/rstb.2001.0888.

217. The Green-Blue Water Coalition (n.d.). Connecting Water, Nature and Business. http://cidadespelaagua.com.br/en/lp-en/. Accessed 26April 2021.

218. The Nature Conservancy (TNC) (2016). How urban trees can save lives: Planting Healthy Air report quantifies health benefits of trees for 245 cities globally, 30 October. https:// www.nature.org/en-us/what-we-do/ourinsights/ perspectives/how-urban-trees-cansave-lives/.Accessed 26 April 2021.

219. UN (2017). Factsheet: People and Oceans. New York, 5-9 June 2017. https:// www.un.org/sustainabledevelopment/wpcontent/uploads/2017/05/Ocean-fact-sheetpackage.pdf.

220. UN (2018). Sustainable Development Goal 6: Synthesis Report on Water and Sanitation. New York, USA: United Nations. 
221. UN (2020a). Climate emergency 'a danger to peace', UN Security Council hears. UN News, $24 \mathrm{July}$. https://news.un.org/ en/story/2020/07/1068991.

222. UN (2020b). International Mountain Day. https://www.un.org/en/observances/ mountainday. Accessed 26 April 2021.

223. UNCCD (2011). Report on the scientific peer review for the refinement of the set of impact indicators on strategic objectives 1, 2 and 3. Note by the secretariat. ICCD/COP (10)/CST/INF.1. h t t p : / www. un c c d. in t / Lis t s / OfficialDocuments/cop10/cstinf1eng.pdf.

224. UNCCD (2017). The Global Land Outlook: First Edition. Bonn, Germany: UNCCD.

225. UNCCD (2018). Caux Dialogue on Land and Security: creating landscapes of peace, 27 July. https://www.unccd.int/news-events/cauxdialogue-land-and-security-creatinglandscapes-peace. Accessed 26 April 2021.

226. UNCTAD (2018). Review of Maritime Transport 2018. New York, USA: United Nations Publications.

227. UNEP (2014). The Importance of Mangroves to People: A Call to Action. van Bochove, J., Sullivan, E. and Nakamura, T. (eds). Cambridge, UK: UN Environment Programme World Conservation Monitoring Centre(WCMC).

228. UNEP (2016). Options for Ecosystem-based Adaptation (EBA) in Coastal Environments: A Guide for Environmental Managers and Planners. Nairobi: United Nations Environment Programme.

229. UNEP (2017). Coral Bleaching Futures: Downscaled Projections of Bleaching Conditions for the World's Coral Reefs, Implications of Climate Policy and Management Responses. Nairobi: United Nations Environment Programme.

230. UNEP (2019a). Addressing marine plastics: A systemic approach - Recommendations for Actions. Notten, P. Nairobi: United Nations Environment Programme.

231. UNEP (2019b). Global Environment Outlook GEO-6: Healthy Planet, Healthy People. Nairobi. https://doi.org/ 10.1017/ 9781108627146.
232. UNEP (2020a). Out of the Blue: The Value of Seagrasses to the Environment and to People. Nairobi: UNEP.

233. UNEP (2020b). The world's biggest ecosystem restoration project, 23 April. ht t p s: / / w w w. une p. org / new s - and stories/story/worlds-biggest-ecosystemrestoration-project. Accessed 26 April 2021.

234. UNEP (2021). Making Peace with Nature: A Scientific Blueprint to Tackle the Climate, Biodiversity and Pollution Emergencies. Nairobi: UNEP. https://www.unep.org/ resources/making-peace-nature.

235. UNEP (forthcoming) Natural Capital in Inclusive Wealth for Pakistan: Evidence from Restoration, Nairobi.

236. UNEP and FAO (2020). Strategy for the UN Decade on Ecosystem Restoration. https://www.decadeonrestoration.org/strategy. Accessed 26 April 2021.

237. UNEP and ILRI (2020). Preventing the Next Pandemic: Zoonotic diseases and how to break the chain of transmission. Nairobi: UNEP and International Livestock Research Institute. https://www.unep.org/resources/report/preventi ng-future-zoonotic-disease-outbreaksprotecting-environment-animals-and.

238. UNEP and United Nations Development Programme [UNDP] (2012). The Role of Natural Resources in Disarmament, Demobilization and Reintegration: Addressing Risks and Seizing Opportunities. Nairobi: U N E P ; N e w Y o r k : U N D P. https://postconflict.unep.ch/publications/UNE P_UNDP_NRM_DDR.pdf.

239. UNEP, GRID-Arendal (2020). Elevating Mountains in the Post-2020: Global Biodiversity Framework 2.0. Arendal, Norway: UNEP, GRID-Arendal, GMBA, MRI.

240. UNEP, International Sustainability Unit [ISU], International Coral Reef Initiative [ICRI] and Trucost (2018). The Coral Reef Economy: The Business Case for Investment in the Protection, Preservation and Enhancement of Coral Reef Health. https://www.icriforum.org/wpcontent/uploads/2019/12/The\%20Coral\%20Re ef\%20Economy-EXECSUM-.pdf. 
241. UNEP, World Economic Forum, ELD. (forthcoming). State of Finance for Nature: Tripling Investments in Nature-based Solutions by 2030. Nairobi: UNEP, WEF and ELD.

242. United Nations [UN] (2016). WHO Global Urban Ambient Air Pollution Database (update 2016). https://www.who.int/ airpollution/ data/cities-2016/en/. Accessed 26 April 2021.

243. United Nations Convention to Combat Desertification [UNCCD] (n.d.). Land and Human Security. https://www.unccd.int/ issues/land-and-human-security. Accessed 26 April 2021.

244. United Nations Educational, Scientific and Cultural Organization [UNESCO] (2017). Facts and figures on marine biodiversity. http://www.unesco.org/new/en/naturalsciences/ioc-oceans/focus-areas/rio-20ocean/blueprint-for-the-future-wewant/marine-biodiversity/facts-and-figures-onmarine-biodiversity/. Accessed 26 April 2021.

245. United Nations Framework Convention on Climate Change [UNFCCC] (2020). Chile's Nationally Determined Contribution: Update 2020 . https://www4.unfccc.int/ sites/ndcstaging/PublishedDocuments/Chile\% 20First/Chile\%27s_NDC_2020_english.pdf. Accessed 26 April 2021.

246. United Nations General Assembly [UNGA] (2019). Resolution 73/284. United Nations Decade on Ecosystem Restoration (2021-2030). A/RES/73/284.

247. United Nations Habitat [UN Habitat] (2020). World Cities Report 2020: The Value of Sustainable Urbanization. Nairobi: United Nations Human Settlements Programme.

248. United Nations High Commission on Refugees [UNHCR] (2020). Global Trends Forced Displacement in 2019. Copenhagen: UNHCR Global Data Service.

249. United Nations High-Level Committee on Programmes [UN HLCP] (2021). A common approach to integrating biodiversity and naturebased solutions for sustainable development into the UN's policy and programme planning and delivery. United Nations High-Level Com mit t e o n Program m e s. CEB/2021/HLCP41/CRP.2
250. United Nations Water [UN Water] (2021). Summary Progress Update 2021: SDG 6 - Water and Sanitation for All. Geneva: UN Water.

251. United Nations. (2020). The UN Decade on Ecosystem Restoration Strategy. 51. https://www.decadeonrestoration.org/strategy.

252. Unruh, J. and Williams, R.C. (2013). Land: A foundation for peacebuilding. In Land and PostConflict Peacebuilding. Unruh, J. and Williams, R.C. (eds.). London, UK: Earthscan.

253. van Meerveld, H. J. (I), Jones, J. P. G., Ghimire, C. P., Zwartendijk, B. W., Lahitiana, J., Ravelona, M. and Mulligan, $M$. (2021). Forest regeneration can positively contribute to local hydrological ecosystem services: Implications for forest landscape restoration. Journal of Applied Ecology 58(4), 755-765. https://doi.org/https://d oi.org/10.1111/1 365-2664.13836.

254. Vié, J-C., Hilton-Taylor, C. and Stuart, S.N. (2009). Wildlife In A changing world: An analysis of the 2008 IUCN Red List of Threatened Species. Gland: IUCN.

255. Wada, Y., Flörke, M., Hanasaki, N., Eisner, S., Fischer, G., Tramberend, S., et al. (2016). Modeling global water use for the 21st century: the Water Futures and Solutions (WFaS) initiative and its approaches. Geoscientific Model Development 9(1), 175-222. https://doi.org/10.5194/gmd-9-175-2016.

256. Wæhler, T.A. and Dietrichs, E.S. (2017). The vanishing Aral Sea: Health consequences of an environmental disaster. Tidsskrift Den Norske Legeforening 137(18). doi: 10.4045 /tidsskr.17.0597.

257. Waltham, N. J., Elliott, M., Lee, S. Y., Lovelock, C., Duarte, C. M., Buelow, C., Simenstad, C., Nagelkerken, I., Claassens, L., Wen, C. K. C., Barletta, M., Connolly, R. M., Gillies, C., Mitsch, W. J., Ogburn, M. B., Purandare, J., Possingham, H., and Sheaves, M. (2020). UN Decade on Ecosystem Restoration 2021-2030-What Chance for Success in Restoring Coastal Ecosystems? Frontiers in Marine Science, 7(February 2020), 1-5. https://doi.org/10.3389/fmars.2020.00071

258. Western Ghats forest cover improved after active ecological restoration (2019); By 
Sandhya Ramesh; (https://theprint.in/science/ western-ghats-forest-cover-improved-activeecological-restoration/300151/)

259. Wetlands International (2018). Degradation of wetlands contributes to social instability and i n s e c u r i t y, 29 A u g u s t . https://www.wetlands.org/news/degradationwetlands-contributes-social-instabilityinsecurity/.Accessed 26 April 2021.

260. WHO and CBD (2015). Connecting Global Priorities: Biodiversity and Human Health A State of Knowledge Review. Geneva and Montreal: World Health Organization (WHO) and Secretariat of the Convention on Biological Diversity (CBD).

261. World Economic Forum [WEF] (2020). The Global Risks Report 2020. Geneva: World Economic Forum.

262. World Health Organization [WHO] (2017). One Health - QandA, 21 September. https://www. who.int/news-room/q-adetail/one-health. Accessed 26 April 2021.

263. World Wildlife Fund [WWF] (2020). Bankable Nature Solutions: Blueprints for Bankable Nature Solutions from Across the Globe to Adapt to and Mitigate Climate Change and to Help our Living Planet Thrive. Netherlands: WWF.

264. Worthington, T. A., Andradi-Brown, D. A., Bhargava, R., Buelow, C., Bunting, P., Duncan, C., et al. (2020). Harnessing big data to support the conservation and rehabilitation of mangrove forests globally. One Earth 2(5), 429443. https://doi.org/ 10.1016/ j.oneear.2020.04.018.

265. Worthington, T. and Spalding, M. (2018). Mangrove Restoration Potential: A global map highlighting a critical opportunity. IUCN, University of Cambridge, and The Nature Conservancy.

266. Xu, J., Badola, R., Chettri, N., Chaudhary, R. P., Zomer, R., Pokhrel, B., et al. (2019). Sustaining Biodiversity and Ecosystem Services in the Hindu Kush Himalaya. In The Hindu Kush
Himalaya Assessment: Mountains, Climate Change, Sustainability and People. Wester, P., Mishra, A., Mukherji, A. and Shrestha, A.B. (eds.). 127-165. Springer International Publishing. https://doi.org/10.1007/978-3-31992288-1_5.

267. Ye, Y., Cochrane, K., Bianchi, G., Willmann, R., Majkowski, J., Tandstad, M. and Carocci, F. (2013). Rebuilding global fisheries: The World Summit Goal, costs and benefits. Fish and Fisheries 14, 174-185. https://doi.org/ 10.1111/j.1467-2979.2012.00460.x.

268. Yu X., Jiang, L., Li L., Wang, J., Wang, L., Lei, G. and Pittock, J. (2009). Freshwater management and climate change adaptation: Experiences from the central Yangtze in China. Climate and Development, 1:3, 241-248, https://doi.org/10.3763/cdev.2009.0023.

269. Zero Budget Natural Farming [ZBNF] (no date). Zero Budget Natural Farming. Official Website of ZBNF Programme of Rythu Sadhikara Samstha, Government of Andhra Pradesh. http://apzbnf.in/.

270. Zhang, X.Q. (2016). The trends, promises and challenges of urbanisation in the world. Habitat In ternational 54 ( 3 ), 241 - 252 . https://doi.org/10.1016/j.habitatint.2015.11.01 8.

\section{Websites (URLs) consulted}

1. http://www.dappzambia.org/news-from-theprojects/211-dapp-zambia-chaz-join-forces-toavert-hiv-aids-tb

2. https://ec.europa.eu/eurostat/statisticsexplained/index.php?title=File:SDG_tradeoffs_2021.png

3. https://www.decadeonrestoration.org/

4. https://www.ser.org/page/DecadeonRestoration

5. https://www.ser-rrc.org/what-is-ecologicalrestoration/

6. https://www.unep.org/news-and-stories/pressrelease/new-un-decade-ecosystem-restorationoffers-unparalleled-opportunity 